NBER WORKING PAPER SERIES

\title{
WORK INCENTIVES AND THE FOOD STAMP PROGRAM
}

\author{
Hilary Williamson Hoynes \\ Diane Whitmore Schanzenbach \\ Working Paper 16198 \\ http://www.nber.org/papers/w16198
}

\author{
NATIONAL BUREAU OF ECONOMIC RESEARCH \\ 1050 Massachusetts Avenue \\ Cambridge, MA 02138 \\ July 2010
}

We are grateful to Bob Schoeni and Donna Nordquist for help with the PSID. Alan Barreca and Rachel Henry Currans-Sheehan provided excellent research assistance. Schanzenbach thanks the Joint Center for Poverty Research USDA Food Assistance and Nutrition Research Innovation and Development Grants in Economics Program and the Population Research Center at the University of Chicago for generous financial support. The views expressed herein are those of the authors and do not necessarily reflect the views of the National Bureau of Economic Research.

NBER working papers are circulated for discussion and comment purposes. They have not been peerreviewed or been subject to the review by the NBER Board of Directors that accompanies official NBER publications.

(C) 2010 by Hilary Williamson Hoynes and Diane Whitmore Schanzenbach. All rights reserved. Short sections of text, not to exceed two paragraphs, may be quoted without explicit permission provided that full credit, including $(\subset$ notice, is given to the source. 
Work Incentives and the Food Stamp Program

Hilary Williamson Hoynes and Diane Whitmore Schanzenbach

NBER Working Paper No. 16198

July 2010

JEL No. H31,J22

\begin{abstract}
Labor supply theory makes strong predictions about how the introduction of a social welfare program impacts work effort. Although there is a large literature on the work incentive effects of AFDC and the EITC, relatively little is known about the work incentive effects of the Food Stamp Program and none of the existing literature is based on quasi-experimental methods. We use the cross-county introduction of the program in the 1960s and 1970s to estimate the impact of the program on the extensive and intensive margins of labor supply, earnings, and family cash income. Consistent with theory, we find modest reductions in employment and hours worked when food stamps are introduced. The results are larger for single-parent families.
\end{abstract}

Hilary Williamson Hoynes

Department of Economics

University of California, Davis

One Shields Ave.

Davis, CA 95616-8578

and NBER

hwhoynes@ucdavis.edu

Diane Whitmore Schanzenbach

School of Education and Social Policy

Northwestern University

Annenberg Hall, Room 205

2120 Campus Drive

Evanston, IL 60208

and NBER

dws@northwestern.edu 


\section{Introduction}

A central question in public finance, one that has generated decades of research, is how tax and transfer programs affect labor supply. The early literature typically estimated cross sectional models thereby ignoring the endogeneity of net wages, net income, and selection into transfer programs. Concerns about biases from these cross sectional approaches led to methodological innovations, in particular structural modeling in the presence of kinked budget constraints. ${ }^{1}$ Structural approaches had their own limitations, including concerns about sensitivity to choice of utility function, stochastic assumptions, and so on. The "new public finance" approach followed, with a reliance on using policy-induced variation and quasi-experimental methods to analyze impacts on labor supply. Quasi-experimental approaches have been used to analyze the impact of wide range of policies on labor supply such as federal taxes, the Earned Income Tax Credit, Medicaid, social security, and welfare reform.

Our paper contributes to the literature on taxes, transfers and labor supply by using a quasiexperimental approach to estimate the impact of the food stamp program (FSP) on labor supply. The FSP is a federal means tested program, providing benefits to buy food for families who are income and asset eligible. Importantly, while the primary goal of the food stamp program is to increase food consumption, Hoynes and Schanzenbach (2009) show that most households are inframarginal and thus food stamp benefits can be treated as an income transfer.

Food stamp benefits are the fundamental safety net in the U.S., being the only public assistance program that is available to all family types (most programs are targeted on female headed households, children, or the elderly). In fact, Food stamps is the largest cash U.S. cash or near cash means tested transfer program with spending in 2009 of 50 billion dollars compared to 30 billion for

\footnotetext{
${ }^{1}$ For example, innovating papers that use structural models applied to kinked budget constraints include Burtless and Hausman (1978) analyzing the negative income tax, Hausman (1980) on the federal income tax, and Moffitt (1983) on AFDC.
} 
TANF and 40 billion for the federal EITC. ${ }^{2}$ The importance of the FSP program is particularly apparent in the current great recession, where more than 1 in 9 persons is receiving food stamps.

Today, food stamp benefits (recently renamed Supplemental Nutrition Assistance Program or SNAP benefits) are paid via electronic debit card that can be swiped at the checkout line like a debit card, and can be used to purchase most grocery store food goods. Recipients are allotted a benefit amount $B$ equal to the difference between the federally defined maximum benefit level for a given family size (i.e. $G$, the guarantee amount) and the amount that the family is deemed to be able to afford to pay for food on its own according to the benefits formula (essentially 30 percent of cash income, less some deductions). During the time period studied here, the program was slightly different. Through 1978, there was a "purchase requirement" which allowed recipients to buy $G$ dollars worth of food stamp coupons for a price $P$ set by a federal schedule and capped to be no higher than 30 percent of income $Y{ }^{3}$ The difference between $G$ and $P$ is called the "bonus coupon amount" and is analogous to today's benefit level. During this period, benefits were paid out via coupons that were slightly smaller than dollar bills that could be used to purchase almost all food goods at grocery stores. ${ }^{4}$

A central challenge for the empirical food stamp literature is that the program is federal and exhibits no variation across states, which is an approach commonly used in the quasi-experimental literature. ${ }^{5}$ Further, the universal nature of the program means there are no ineligible groups to serve as controls, which is another common approach in the quasi-experimental literature. Instead, the

\footnotetext{
${ }^{2}$ Food stamp program statistics are available at http://www.fns.usda.gov/pd/SNAPsummary.htm; AFDC/TANF statistics are available at http://www.acf.hhs.gov/programs/ofa/data-reports/index.htm, and EITC program data is available at http://www.taxpolicycenter.org/TaxFacts/index.cfm.

${ }^{3}$ In practice, the price averaged about 25 percent of income for a family of 4. See Appendix Table 4 for the 1969 price schedule.

${ }^{4}$ Benefits cannot be used for hot food intended for immediate consumption, vitamins, alcohol, pet food or paper products. During the time period studied in this paper, they also could not be used to purchase food that was "obviously imported".

${ }^{5}$ There was some cross-state variation in eligibility standards in the earliest years until federal standards were adopted in the January 1971 amendments to the Food Stamp Act.
} 
typical food stamp study in some way compares recipients to nonrecipients leading to a possible bias if there is selection into program participation (Currie 2003). The small existing literature on the labor supply effects of the food stamp program uses structural estimation with little attention to exogenous variation in the program. ${ }^{6}$

In this paper, we take a very different approach to estimating the labor supply effects of the FSP using the introduction of the program as it was phased in across U.S. counties over a relatively gradual period. We utilize the natural experiment afforded by the nationwide roll-out of the modern Food Stamp Program during the 1960s and early 1970s. Our identification strategy uses the sharp timing of the county-by-county rollout of the FSP, which was initially constrained by congressional funding authorizations (and ultimately became available in all counties by 1975). While the existing literature limits attention to hours worked, we examine the impacts of the program on labor force participation, annual hours, earnings, and total family cash income. Further, reflecting the universal eligibility in the FSP, we examine impacts on all families, including married couples and female headed households. Our "program introduction" research design has the appeal of relying on nonmarginal changes in incentives faced by consumers. ${ }^{7}$

Safety net programs, such as AFDC, TANF and food stamps, are designed to insure a basic level of consumption in low-income families. Consequently, benefits in traditional income support programs feature a guarantee - a benefit level if the family has no income. As earnings or income increases, benefits are reduced leading to an implicit tax rate on earnings (called the benefit reduction rate or BRR). As described above, benefits in the FSP take this form; for example in 2010 a family of three has a food stamp guarantee of $\$ 526$ per month and the benefit is phased-out using a benefit

\footnotetext{
${ }^{6}$ These studies include Fraker and Moffitt (1988), Hagstrom (1996), and Keane and Moffitt (1998) and are discussed below.

${ }^{7}$ This "program introduction" research design has been taken in recent analyses of other social programs such as Head Start (Ludwig and Miller 2007), Medicare (Finkelstein and McKnight 2008), Title I (Cascio et al. 2006), and in our own prior work on the food stamp program (Almond, Hoynes and Schanzenbach 2010, Hoynes and Schanzenbach 2009).
} 
reduction rate of 30 percent. ${ }^{8}$ Notably, the benefit reduction rate in the food stamp program is lower than the rate under the old AFDC program or most states' TANF programs. ${ }^{9}$

As is well known, a family's labor supply response to the income transfer program may partially offset the income and consumption enhancing goals of the program. The guarantee produces an income effect and the benefit reduction rate reduces the net wage leading to an income and substation effect. Standard static labor supply theory predicts that the program will reduce labor supply on both the extensive (employment) and intensive (hours conditional on work) margins. As a result, it may cost more than $\$ 1$ in income support payments to increase a low-income family's available cash and near-cash resources by $\$ 1$.

We use data from the Panel Study of Income Dynamics (PSID) from 1968-1978 to examine the impact of the FSP on labor supply, earnings, and income. We employ a difference-in-difference model where the treatment is at the county level, with controls for county and year fixed effects and state linear time trends. In this model, identification requires that there are no contemporaneous county level trends that are correlated with food stamp introduction and family economic outcomes. We also estimate a triple difference model that uses variation across subgroups with varying propensities of being affected by food stamps. Our results are robust to adding controls for possible confounders and we also present event study models that further support the validity of the research design.

Overall, our results indicate that people behave as the theory predicts. In the pooled (full) sample we find modest reductions in employment and hours worked after food stamp benefits are introduced. The impacts are larger but also less precisely estimated when limited to female headed households. We find no significant impacts of the FSP on earnings or family income.

\footnotetext{
${ }^{8}$ There are additional deductions for dependent care, child support, medical costs, high housing costs, and 20 percent of earned income.

${ }^{9}$ Up until 1967, the benefit reduction rate in the AFDC program was $100 \%$. It was reduced to $67 \%$ in 1967 , then increased again to $100 \%$ in 1981. After federal welfare reform, and the conversion to TANF, there is substantial variation across states in the programs' BRR.
} 
The remainder of the paper is as follows. Section II summarizes the prior literatures and Section III provides a history and summary of the Food Stamp Program. Section IV describes the expected effects of the FSP on labor supply and Section V describes the data. Section VI presents the results and Section VII discusses the results in the context of the existing literature. Section VIII concludes.

\section{Prior Literature}

While there is a sizable literature examining the impacts of the food stamp program on family consumption, nutrition, and family well-being, there is little research examining its impacts on labor supply. The prior literature, which is based mostly on structural estimation, finds modest impacts of the FSP on labor supply.

The prior studies of the effect of FSP on labor supply include Fraker and Moffitt (1988), Hagstrom (1996), and Keane and Moffitt (1998). Fraker and Moffitt (1988) use structural models and kinked budget constraints to estimate the impact of food stamps on labor supply for a sample of female heads of household. They specify a utility function and model the choice of hours of work (zero, part time, full time) and participation in the AFDC and food stamp programs. Fraker and Moffitt find that the FSP reduces hours of work by participants by 1 hour per week among food stamp recipients, or since mean weekly hours worked for Food Stamp participants is about 9.5, a 9 percent reduction. Keane and Moffitt (1998) extend this paper, also looking at female headed households, by simultaneously modeling AFDC, food stamps, Medicaid and housing benefits. They find larger elasticities than Fraker and Moffitt, but do not report simulations for - effect of the overall FSP on labor supply. Hagstrom (1996) estimates the impact of the FSP on married couple's labor supply using a multinomial logit model. He reports small impacts of changes in the food stamp guarantee and BRR on labor supply but does not report simulations for the total effect of the FSP on labor supply. Notably, all of these studies use cross sectional models where food stamp benefits do 
not vary across families. ${ }^{10}$ Moffitt (2002) summarizes the literature by concluding "the Food Stamp program has little effect on work disincentives." In this paper, we find labor supply effects that are larger than the prior literature.

The vast literature on labor supply effects of a variety of income transfer programs is well summarized elsewhere (Moffitt 1992; Hoynes 1997; Moffitt 2002). The empirical literature on the AFDC program may also be useful here because there is substantial overlap in participation between the two programs. The general findings from the literature on the AFDC program (which provided cash income support) are that AFDC reduces labor supply among program participants by 10 to 50 percent. In particular, the influential paper by Moffitt (1983) finds that annual hours worked by AFDC recipients are 546 lower per year because of the program. This translates into a reduction of 208 hours per year among female headed households as a whole. The earlier work by Hausman (1981) finds even larger effects, a reduction of 1024 hours per year for AFDC recipients. These estimates suggest that income support programs can have large work disincentive effects. Compared to the food stamp program, AFDC benefits and the benefit reduction rate are higher, thus we would expect the work disincentive effects to be lower in the food stamp program.

\section{Introduction of the Food Stamp Program}

President Kennedy's first executive order was to introduce the modern Food Stamp Program by establishing eight county-level programs. The number of pilot programs grew to 43 by 1963 . The pilot programs were seen as a great success, and were credited for improving diets of low-income families while also strengthening markets for farm commodities (Johnson, 1964). Lyndon Johnson expanded the program and made it permanent when he signed the Food Stamp Act on August 31, 1964. The Act gave local areas the authority to introduce a federally funded FSP in their area.

\footnotetext{
${ }^{10}$ The papers use data from a single year, so the food stamp schedule varies only by family size (which is a source of variation not used in these papers). The effective benefit will vary by state since AFDC income is included in a family's countable income (and AFDC payments vary by state).
} 
Counties introduced the program at a steady rate over the next decade, until Amendments to the Food Stamp Act in 1973 required all remaining counties to adopt the program by 1975 .

Figure 1 summarizes the overall pattern of FSP introduction. The figure plots the percent of counties offering FSP, where the counties are weighted by their 1970 population. Note this is not the food stamp caseload, but represents the percent of the national population that lived in an area offering a FSP. The figure shows that there was a long ramp up period between 1964 and 1975, leading to the eventual universal coverage of the FSP. For example in 1967 (our first year of income data from our main data source - the PSID) a bit less than half of the population lived in counties with FSP; by 1972 coverage rose to over 80 percent of the population. According to Berry (1984), funding limits were a major factor in the timing that counties moved off of the waiting list and were able to start up their program: "The program was quite in demand, as congressmen wanted to reap the good will and publicity that accompanied the opening of a new project. At this time there was always a long waiting list of counties that wanted to join the program. Only funding controlled the growth of the program as it expanded" (pp. 36-37).

In this paper we rely on variation across counties in the timing of the original introduction of the FSP to isolate the impact of the program on labor supply behavior. Consequently the causal identification of the impact of FSP relies on the exogeneity of the county implementation of the program. An important starting point is to recognize that counties applied for funds to start a local food stamp program and were funded subject to current allocations by Congress. Notably, the county application was voluntary.

In the early 1960s, some counties provided food aid to the poor via the Commodity Distribution Program (CDP). The Federal government would purchase surplus commodities to support farmers and distribute a portion of them directly to low-income families. The CDP was criticized not only for being inefficient relative to normal market channels for distributing food, but also because the timing of the goods distribution was irregular and only a narrow variety of 
commodities were available. ${ }^{11}$ At the time the Food Stamp Act was signed, only about one-third of families living in poverty were participating in the CDP program. Part of this was likely due to the fact that many counties did not offer the program. ${ }^{12}$ In general, the CDP was preferred by agricultural interests and the FSP was preferred by advocates for the poor.

Because of the 10 year ramp up to countrywide availability of the FSP, we can exploit that variation as a natural experiment of exposure to the program. For this research design to be a valid approach to studying the labor supply impact of the FSP, though, counties' FSP start dates much be exogenous to other underlying county-level trends in labor supply. To explore the exogeneity of FSP adoption, we take several approaches. Below we show event-study analyses that document the absence of pre-trends in our outcomes variables and show a sharp change in measures of labor supply after the FSP is introduced. In addition, here we explore what county-level characteristics predict when counties adopt the program.

Given the politics of the FSP relative to the CDP (Kotz 1969; Berry 1984), we expect that northern, urban counties with large poor populations would likely adopt the FSP relatively earlier, while Southern counties and those with strong agricultural interests in general are likely to adopt the program later. To measure this, we take county-level characteristics measured in 1960 - that is, before even the introduction of the pilot programs - and use them to predict the timing of a county's eventual adoption of FSP. The dependent variable in this analysis is the month and year of the county's food stamp start date expressed as an index equal to 1 in January 1961. The independent variables include the percent of the 1960 population that lives in an urban area, is black, is less than age 5, is age 65 or older, has income less than $\$ 3000$ (in 1959\$), the percent of the county's land used for farming, and log of the county's total population (constructed from the 1960 Census of

\footnotetext{
${ }^{11}$ The most frequently available commodities were flour, cornmeal, rice, dried milk, peanut butter and rolled wheat (Citizens' Board of Inquiry, 1968).

${ }^{12}$ We have not been able to construct a consistent time series for county participation in the CDP, so we are unable to use this information in the empirical analysis.
} 
Population and Census of Agriculture). All regressions are weighted by the 1960 county population. $^{13}$

The results are presented in Appendix Table 1 and include specifications with and without state fixed effects, and with and without the early pilot counties (which were clearly non-random). Positive coefficients indicate that the county characteristic predicts a later FSP start date. We find that counties that have a larger overall population and a higher share that is poor, black, very young, or elderly implement FSP earlier. Consistent with the political history of the program, counties with more land used for farming implement the program later. We also find that the relationship between start date and county characteristics is weaker (in absolute value) in Southern counties. While these results show statistically significant impacts of county characteristics in predicting the timing of the introduction of FSP, the quantitative importance of these characteristics is small and most of the variation remains unexplained. To control for possible differences in trends across counties that may be spuriously correlated with the county treatment effect, we include interactions of the 1960 pretreatment county characteristics with time trends in all of our models (as in Acemoglu et al. 2004 and Hoynes and Schanzenbach 2009). Note that the main effects of the 1960 county characteristics are absorbed by the county fixed effects. The results are little impacted by the inclusion of these trends. These findings are consistent with Berry's characterization that the exact timing of FSP introduction across counties was driven largely by fiscal constraints and not the lack of desire by counties to introduce the program.

The FSP was introduced around the same time as other programs that were part of the federal “war on poverty." For example, this period included the introduction of Medicaid, Medicare, Head Start, and the Supplemental Nutrition Program for Women, Infants and Children (WIC), and saw expansions of AFDC, Social Security, and disability insurance programs. If these other programs

\footnotetext{
${ }^{13}$ We drop observations from Alaska throughout the paper due to inconsistencies in mapping FSP service areas to standard county FIPS codes. Here we also drop the (few) counties where the percent of land used for farming is greater than 100 percent, and very small counties with population less than 1,000 because of missing data.
} 
mainly varied at the state level, then our controls for state linear time trends or state-year fixed effects should absorb their impacts. Nonetheless, to control for possible coincident expansions of other programs we also include annual measures of county per-capita transfer payments for cash income support, medical care, and retirement and disability programs (see data section below).

\section{Labor Supply Predictions of Food Stamp Introduction}

Food stamp benefits have the structure of a traditional income support program, with a guaranteed income benefit which is reduced with family income at the legislated benefit reduction rate. We illustrate the labor-leisure tradeoff with and without food stamps in Figure 2. Like other means-tested programs, the FSP alters the household's labor-leisure tradeoff increasing after tax and transfer income at earnings up to the breakeven point. In particular, the food stamp benefit is largest at zero hours of work, and benefits are reduced as income and earnings are increased leading to an implicit tax rate on earned income. The benefit reduction rate in the food stamp program is 30 percent, which is lower than other means tested transfer programs (e.g. 67 or 100 percent in AFDC, the precursor to TANF). ${ }^{14}$

In Figure 2a, the $\mathrm{x}$ axis measures the amount of leisure consumed, and the $\mathrm{y}$ axis measures total income including the cash value of in-kind transfers through the food stamp program. ${ }^{15}$ Prior to the introduction of the FSP, the budget constraint is a straight line with a slope equal to the individual's wage $W$. The simple static labor supply model states that an individual maximizes her utility subject to this budget constraint, and assuming a positive labor supply choice, chooses some combination of consumption of goods and leisure at points illustrated for consumers with different

\footnotetext{
${ }^{14}$ Today there is a deduction for 20 percent of earnings, and as a result the effective benefit reduction rate is lower than 0.30 . During the early years of the FSP, there was a "purchase requirement" which allowed recipients to buy $G$ dollars worth of food stamp coupons for a price $P$ set by a federal schedule. The price increased by $\$ 3$ for every additional $\$ 10$ in income (see Appendix Table 4 for the 1969 price schedule).

${ }^{15}$ For simplicity we model food stamp benefits as cash in the amount of the face value of the coupons, and assume there are no other welfare programs in place. We ignore the purchase requirement and model the program based on the bonus coupon amount. We also ignore that $F$ is flat across small ranges of incomes. Adding any of these to the model complicates the graphs but does not change the prediction or the intuition.
} 
preferences by $A$ and $A^{\wedge}$, consuming leisure in amount $\ell$ and $\ell^{\wedge}$, respectively. If her offer wage is below her reservation wage (the slope of the indifference curve at zero hours of work) then it will be optimal to remain out of the labor force, as illustrated by point $\tilde{A}$ (at maximum leisure choice $\bar{\ell}$, or hours $=0$ ).

As illustrated in Figure 2b, the introduction of the FSP alters the budget constraint by adding non-labor income $G$, and rotating the slope of the budget constraint to $W(1-t)$ where $t$ is the tax rate on benefits as income increases ( 0.3 during this time period). For the individual supplying zero hours of work and consuming only leisure, consumption opportunities increase by the FSP "guarantee" amount $G$.

As is well known in the analysis of traditional income support programs, this combination of a guaranteed income and benefit reduction rate leads unambiguously to predictions of reductions in the intensive and extensive margins of labor supply. In this case, both the income effect of the benefit as well as the income and substitution effect from the benefit reduction rate leads, unambiguously, to a predicted decline in employment (extensive margin), hours worked (intensive margin), and (if wages are fixed) earnings. In addition, family cash income (which as measured does not include food stamp benefits) would also be predicted to fall. (Of course, family total after transfer income including food stamps is likely to increase.)

Referring back to Figure 2, our representative individual who was, prior to the introduction of the food stamp program, in the labor force and consuming at point $A$, is predicted to increase their leisure (reduce their hours worked) choosing a consumption bundle $A^{\prime}$ ' with leisure amount $\ell^{\prime}$ where $\ell^{\prime}>\ell$. Alternatively, it is possible that the combination of the negative income and substitution effects can push them out of labor market to point $A^{\wedge}$.

As discussed above, the FSP is run by the U.S. Department of Agriculture, and throughout most of its history the benefit and eligibility criteria have been uniform across states. Thus, at a point 
in time, the guarantee and benefit reduction rate are constant across all eligible families of a given family size. ${ }^{16}$ The prior literature examines the period after the FSP was expanded to a national program. Without variation across states that is often utilized in analysis of government programs, the literature relies on structural estimation where the emphasis is on identifying parameters of the utility function. Despite no variation in the FSP program parameters $G$ and $t$, by estimating the parameters of the utility function in the presence of the budget constraint, the studies simulate the effect of marginal changes to the FSP (change in G or t) or out of sample predictions of the total effect of the FSP. Instead, we use the rollout of the FSP in a quasi-experimental difference-indifference design whereby we compare counties that have implemented the FSP to other counties who have not yet implanted. We measure whether family labor supply responds to the introduction of the program as predicted by economic theory. Notably, this is a non-marginal calculation; instead we identify the labor supply with and without the program in place.

\section{Data}

In order to utilize the county-level variation in FSP rollout, we require a dataset that covers as much of the rollout period as possible (1963-1975) and provides information on county of residence. The Panel Study of Income Dynamics (PSID) is a panel data set that began in 1968 with a sample of about 5,000 households. Subsequently all members and descendants of the original survey families were re-interviewed annually. The original 1968 sample consists of two subsamples: a nationally representative subsample of 3,000 households (Survey Research Center subsample) and a subsample of 1,900 households selected from an existing sample of low income and minority populations (Survey of Economic Opportunity subsample). To adjust for this nonrandom composition, the PSID includes weights designed to eliminate biases attributable to attrition, and to the oversampling of low income groups. All analyses use the weights provided by the PSID.

\footnotetext{
${ }^{16}$ The food stamp guarantee, G, varies by size of family.
} 
The central focus of the PSID is labor market and demographic variables, containing substantial detail on income, employment, and family composition. From this, we measure the annual hours worked and annual earnings over the previous year for both the household head and spouse (if applicable), whether the family reports receiving any food stamp benefits, and total annual family cash income (not including the value of food stamps). We use data from interview years 1968 to 1978. ${ }^{17}$ We stop the sample in 1978 because of a significant change in the structure of food stamp payments that begins in $1979 .{ }^{18}$

We limit the sample to include families with a family head that is less than 65 . We exclude elderly families because they have lower food stamp takeup rates (see Appendix Table 2) and are less attached to the labor market. Our nonelderly headed sample consists of 48,168 family-year observations. In some specifications, we limit the sample to nonelderly heads with a high school education or less (37,474 observations), female headed households with children (7,280 observations), or nonwhite, female headed households with children (5,464 observations) to represent samples with a higher FSP participation rates. Note, unlike other means tested transfer programs, the FSP is available to married and unmarried families alike as long as they are income eligible. Reflecting their lower family incomes, however, female headed households have significantly higher eligibility and participation rates compared to their married counterparts.

Appendix Table 3 presents some basic descriptive statistics for the main analysis samples. All dollar amounts are in 2005 dollars. Over 90 percent of heads report working at some point in the previous year in the overall sample, with 1,947 average annual hours. Female headed households report much lower rates of employment (71 percent overall, and 62 percent for nonwhite female heads) and hours worked (1068 and 864, respectively).

\footnotetext{
${ }^{17}$ We have to drop the food stamp variable for the 1969 interview year because the survey does not separate FSP benefits from other sources of food assistance (e.g. commodity distribution program, other in-kind benefits) in that year. This reduces our sample sizes when FSP participation is the dependent variable.

${ }_{18}$ Most notably, the purchase requirement was eliminated. As a result, participants were simply given stamps worth the bonus coupon amount $B$ instead of having to purchase the entire $G$ amount of food stamps at a discounted price.
} 
The public-use release of the PSID includes only state level identifiers for each family-year. Through special arrangement, we have obtained county level identifiers for each family in each year. We merge the PSID data using these county identifiers with three additional data sets of county variables. First, the key treatment or policy variable is the month and year that each county implemented a food stamp program, which comes from USDA annual reports on county food stamp caseloads (USDA, various years). We code the FSP policy variable equal to one if the respondent's county of residence has the program by January of that year. ${ }^{19}$ Second, the 1960 City and County Data Book—which compiles data from the 1960 Census of Population and Census of Agriculture—is used to measure economic, demographic, and agricultural variables for the counties pre-treatment (before FSP is rolled out) period. In particular, we use: the percent of the 1960 population that lives in an urban area, is black, is less than 5, is 65 or over, has income less than $\$ 3,000(1959 \$)$, the percent of land in the county that is farmland, and log of the county population. Finally, we use Bureau of Economic Analysis, Regional Economic Information System (REIS) data to construct annual, county real per capita income and government transfers to individuals, including cash public assistance benefits (Aid to Families with Dependent Children AFDC, Supplemental Security Income SSI, and General Assistance), medical spending (Medicare and Military health care), and cash retirement and disability payments for each county-year.

\section{Results}

\section{a. Difference-in-Difference Approach}

We begin by estimating a difference-in-difference model using the 1968-78 PSID. This compares labor supply measures across counties and over time relative to when the FSP was introduced. Specifically, we estimate the following model:

\footnotetext{
${ }^{19}$ This is measured for the same year as is reported on in the annual labor supply and income data. That is, since the 1968 survey asks about labor supply and income during calendar year 1967, the corresponding FSP variable for that year reflects availability of the program in their county in 1967.
} 


$$
y_{i c t}=\alpha+\delta F S P_{c t}+X_{i t} \beta+\sigma C B 60_{c} * t+\gamma R E I S_{c t}+\eta_{c}+\lambda_{t}+\mu_{s t}+\varepsilon_{i c t}
$$

where $y_{i c t}$ is the outcome variable (such as head's employment status or annual hours worked) for family $i$ living in county $c$ in year $t . F S P_{c t}$ is an indicator variable equal to one if there is a Food Stamp Program in county $c$ at time $t . X_{i t}$ are family demographic characteristics (urban residence, education and race of head, female headed household indicator, and state unemployment rate), $C B 60_{c}$ are 1960 county characteristics (interacted with linear time), and $R E I S_{c t}$ are county-level per capita income transfer program data, $\eta_{c}$ and $\lambda_{t}$ are county- and year-fixed effects respectively, and $\mu_{s t}$ are either state-specific linear time trends or state by year fixed effects.

As described in Section IV above, we include pre-treatment county characteristics $(C B 60)$ interacted with linear time trends to control for the observable determinants of county food stamp adoption. The variables in $C B 60$ include the percent of land in farming and the percent of population black, urban, age less than five, age greater than 65 and with income less than $\$ 3,000$. We also include per-capita county income transfers $\left(R E I S_{c t}\right)$ for (1) retirement and disability programs, (2) medical care (Medicare, Medicare, and military health care), and (3) cash public assistance (AFDC, SSI, and general assistance) to control for coincident introduction or expansion of other programs that are not swept out by state linear time trends or state*year fixed effects. All estimates are weighted using the PSID family weight, and standard errors are clustered at the county level.

Results are presented in Table 1. Each cell provides estimates from a separate regression and only the coefficient on the FSP availability variable is reported (along with the mean of the dependent variable). Columns (1)-(2) cover all non-elderly families. Panel A presents the "first stage" impact of program introduction on an indicator variable for whether the family reports any receipt of food stamps in that year. We find that about 3 percent of the overall sample reports receiving food stamps when the program is in place. The dependent variables in panels B through D are whether the head reported any employment during the year, the head's annual hours, and the 
head's annual earnings, and the dependent variable in panel $\mathrm{E}$ is the log of total family cash income. Two specifications are reported for each subsample - the odd columns use state linear time trends and the even columns use state-by-year fixed effects. ${ }^{20}$ State-by-year fixed effects may do a better job accounting for concurrent expansion in other welfare programs. The results are largely unchanged when state-by-year effects are included.

The results in column (1) and (2) indicate no effect of FSP introduction on head's work behavior in the overall nonelderly population. Note that hours and earnings are unconditional measures - that is, they include zero values for nonworkers. Any measured effect, therefore, can come about from a change in the extensive or intensive margins of work. We similarly find in Panel E no impact of FSP on log of family income.

Our identification strategy is based on the introduction of a county-level FSP program, but only the low-income residents of treated counties who are eligible to enroll (and, further, who actually do enroll in the program) should be directly impacted by the program. As shown in Appendix Table 2, program participation varies widely with education, race and family type. ${ }^{21}$ To account for this, we first limit the overall sample to sub-groups that are likely to be impacted by the program (and similarly, in Table 3 we show placebo regressions limited to sub-groups that are unlikely to be impacted by the program).

Columns (3)-(4) limit the sample to nonelderly families with a head who has 12 or fewer years of education. The first stage results in Panel A show that 4.3 to 4.8 percent of families report receiving food stamp benefits after the program is introduced in their county. There is no evidence that head's work effort declines in response to the program. In fact when state-by-year fixed effects are included, head's work force participation the prior year actually increases by a statistically

\footnotetext{
${ }^{20}$ The sample sizes change slightly in this specification because we drop observations if the state-year cell has fewer than five observations.

${ }^{21}$ The table calculates FSP participation rates for families by the head's race, marital status, and educational attainment, and presence of children using the PSID pooled over the years 1976-78, which is the period in our data after the FSP was implemented in all counties.
} 
significant 2 percentage points. The coefficients on head's annual earnings and family income are negative, but never statistically significant.

Columns (5)-(6) limit the sample to female-headed families. This sample reports participating in the program at much higher rates: between 19 and 22 percent report receiving benefits after the program is introduced in their county. Employment and earnings responses for this sample are completely in line, although not always statistically significantly, with the theoretical predictions outlined in Figure 2. Among all female heads, the point estimate on annual employment status shows a statistically insignificant 4 percentage point reduction with FSP introduction. Further, although employment rates do not change, there is evidence that female heads reoptimize along the intensive margin as predicted by economic theory by reducing their annual hours of work. In the specification controlling for linear time trends, annual hours are reduced by an average of 183 hours (on a mean of 1068). The results are slightly larger when state-by-year fixed effects are included in the model. Head annual earnings and log of family income both appear to decline as well, but the effects are not precisely estimated.

Finally, we further limit the sample to nonwhite female-headed families in columns (7)-(8). The estimated first stage of food stamp takeup rate is largest for these families with an estimated 25 to 38 percent reporting receipt of food stamps after the program is introduced. These families appear to adjust on the extensive margin, with estimates varying from insignificant 4.8 to a statistically significant 9.7 percentage point reduction in labor force participation. Annual hours worked and earnings (which, as noted above, include zeros for non-workers) decline commensurately and are statistically significantly different from zero. The impact on overall family cash income is imprecise and not consistently signed across the specifications.

The estimates in Table 1 represent average treatment effects across the sub-sample, which includes FSP participants and nonparticipants. We can use the average participation rates in Appendix Table 2 to convert the estimates to the implied treatment on the treated (TOT) effect by 
dividing the coefficient by the sample's FSP participation rate. ${ }^{22}$ This suggests a TOT effect on annual hours of 500-650 hours for female headed households and 289-517 for nonwhite female headed households.

Existing evidence suggests that the labor supply of a family's secondary worker is more responsive to income transfer programs, so we might expect the spouse's labor supply to decline by more than the head's in a married-couple family (Eissa and Hoynes 2006; Hoynes 1996). To test this, in Table 2 we present results limited to married couple families and show the impact of FSP introduction on labor supply separately for heads and spouses. ${ }^{23}$ As in Table 1, the odd columns control for state-by-linear time trends while the even columns include state-by-year fixed effects. Columns (1) and (2) present results for all nonelderly married families. Only 2 percent of families in this sample report receiving benefits after the FSP is introduced. There is no evidence in this sample that heads or spouses alter their labor supply efforts in response to the introduction of the program. Head's annual employment status, hours and earnings are never statistically significantly impacted by FSP introduction, and the point estimate is usually positive. Spouse's employment behavior in this overall sample is never statistically significantly impacted although the point estimates are consistent with a work disincentive effect of food stamps.

In columns (3) and (4) we target the sample to married couples where the head has a high school diploma or less. Here the takeup rate of the program is only slightly higher -3 percent of the sample reports receiving benefits - and the impacts on head and spouse labor supply are also reasonably precisely estimated zeroes. The results so far suggest that it is primarily single female household heads that alter their labor supply in response to the FSP.

\footnotetext{
${ }^{22}$ We inflate by the participation rates in Appendix Table 2 instead of the (smaller) coefficient from Panel A for consistency with the triple-difference results reported further below.

${ }^{23} \mathrm{In}$ most, but not all families, the head is male and the spouse is female. For this reason we will continue to use the terms head/spouse rather than husband/wife.
} 
As a check to insure that the labor market findings are not spurious, in Table 3 we present placebo regressions looking for signs of an "effect" of the FSP on groups that are unlikely to have received treatment. Columns (1) and (2) report results for all high-income (defined as annual income greater than $\$ 50,000$ in inflation-adjusted 2005 dollars) families, the next pair of columns limits the sample to high-income married couples with children, and the final pair limits the sample even further to white married high-income families with children. As shown in Panel A, these families are very unlikely to report receiving any food stamp benefits. The coefficients on head's employment, hours worked and earnings are small and not statistically different from zero. The sign on annual earnings is generally wrong-signed - indicating an increase in earnings after FSP is introduced in their county - with sizeable standard errors. Effects on spouse reporting any employment here are small and generally wrong-signed, while spousal hours worked and earnings bounce around and are imprecise. These findings indicate that there is no "treatment effect" on families that do not receive treatment and lend further credibility to our research design.

\section{b. Triple-difference approach}

Unlike virtually all other U.S. public assistance programs, there is no categorical eligibility for the food stamp program. That is, eligibility depends on income and asset tests but it is not targeted to particular demographic groups, such as single parents with children. This argues for using broad samples, such as all nonelderly families or low educated nonelderly families as we did above. However, it is clear from the analysis in Tables 1 and 2 that we may not have the power to detect effects in a broad sample.

At the same time, the participation rates in Appendix Table 2 show that while food stamp participation is highest among single parent families with children, the participation is widespread

and varying across many demographic groups. For example, among families where the head has less than 12 years of education, 14 percent of married couples with children and 14 percent of single nonelderly persons with no children participate in food stamps (compared to 46 percent of single 
parent families with children). The rates are uniformly higher among black families, with 56 percent of single nonelderly parent families with children (where the head has less than 12 years of education) participating in food stamps.

In the end, in choosing our preferred sample for this analysis, we face a tradeoff between sample size (using the larger sample of nonelderly families but with overall lower participation rates) and targeting (using the smaller sample female heads of household with higher participation rates). Here, we refine these earlier results by using the nonelderly sample, but adopting a triple-difference specification that accounts for different probabilities of being affected by food stamps. Using the participation rates in Appendix Table 2, we consider 24 groups $g$ that are defined by race (white, nonwhite), marital status (married, not married), presence of children (yes, no), and educational attainment $(<12,12,>12)$. Following Bleakley (2007) and Hoynes and Schanzenbach (2009), we use these participation rates $\left(P_{g}\right)$ to scale the food stamp treatment variable, and estimate the following model where the unit of observation is the family-year:

$$
y_{i c t}=\alpha+\varphi F S P_{c t}+\delta F S P_{c t} P_{g}+\sigma C B 60_{c} * t+\gamma R E I S_{c t}+\theta_{g}+\theta_{g} * t+\eta_{c}+\lambda_{t}+\mu_{s t}+\varepsilon_{i c t}
$$

In addition to the variables include in equation (1), we also include fixed effects for group and group linear time trends. We include the main effect for FSP as well as the interaction with $P_{g}$. The coefficient on the main effect can be interpreted as the impact on a group with zero risk of being on food stamps, and we therefore expect the coefficient on the main effect to be zero.

The results are presented in Table 4. In column (1) we include state linear time trends, in column (2) we include state by year fixed effects, and in column (3) we augment equation (2) with interaction terms between $P_{g}$ and all control variables. This is a triple-difference specification: across counties, over time, and across groups. Because we inflate by participation rate, the coefficient of interest, $\delta$, can be interpreted as the impact of the treatment on the treated. 
The results in Table 4 are consistent with the theoretical predictions that the introduction of an income support program induces households to consume more leisure. Further, the results are remarkably consistent across specifications. Participating heads reduce employment by 24 to 27 percentage points when the FSP is introduced in the county. Head's annual hours also appear to decline with p-values hovering just over 10 percent. The point estimates on earnings and log family income suggest a commensurate decline, but the estimates never approach statistical significance. In each case, as expected, the coefficients on the main effect for FSP are uniformly small and not different from zero. This is a placebo-test of sorts and the small coefficients give us additional confidence about the validity of our design.

Table 5 repeats the specifications described above but limits the sample to married couples with a spouse present. Head's labor supply is not statistically significantly affected by the introduction of FSP, though all point estimates are negative. The same pattern holds for spouse's labor supply. Employment, hours and earnings all have a negative point estimates but are not statistically significantly different from zero. We do find that, relative to their baseline values, these responses are larger for spouses than heads as predicted from the literature.

\section{c. Event study analysis}

Our results so far have been quite robust to different ways of controlling for confounding background characteristics. This suggests that our results are identified off of discrete changes in outcomes at the time of FSP introduction. If instead identification were being driven by underlying trends or variation in other characteristics, we would expect more sensitivity of our coefficients to changes in the manner we account for these possible confounders.

To directly examine the timing of the shifts in labor supply relative to the introduction of FSP, we return to the female headed household sample and conduct an event study analysis. We use the female headed household sample because they have the highest FSP participation rates and largest responses to FSP introduction in the results presented above. The event study approach 
requires a discrete treatment, so using the full sample with adjustment for group specific participation rates does not lend itself to this approach.

The advantage of an event study analysis is it traces out the trend in labor supply year-byyear for the periods leading up to and following FSP adoption. This allows for rigorous testing of a "pre-trend," the presence of which would raise concerns about our identification strategy. It also allows for an analysis of the dynamics of the policy effect - for example whether they grow with time since adoption. We are able to estimate an event study analysis here because we have a discrete policy variable that is implemented at different times across the counties in our sample.

Specifically, we estimate the following equation:

$$
y_{i c t}=\alpha+\sum_{j=-3}^{3} \pi_{j} 1\left(\tau_{c t}=j\right)+\sigma C B 60_{c} * t+\gamma R E I S_{c t}+\eta_{c}+\lambda_{t}+\mu_{s t}+\varepsilon_{i c t}
$$

where $\tau_{\mathrm{ct}}$ denotes the year relative to the introduction of the FSP, defined so that $\tau_{\mathrm{ct}}=0$ if for county $c$ the FSP began at any point in calendar year $t$. For $\tau_{\mathrm{ct}}<0$, work effort decisions were made prior to the introduction of the FSP. All coefficients are measured relative to the omitted coefficient $\left(\tau_{\mathrm{ct}}=-1\right)$. We run the model with and without the inclusion of our controls for potential FSP policy endogeneity (that is, the 1960 county characteristics interacted with linear time trends and REIS county controls) and include state linear time trends $\left(\mu_{\mathrm{st}}\right)$. In order to eliminate potential compositional effects, we restrict the sample to a balanced panel of counties having observations for all 7 event periods ( 3 years prior to FSP implementation and 3 years afterwards). Because our data begin in 1968, this means we exclude counties where FSP started in 1970 or earlier.

We produce event study graphs for each of the labor supply outcomes for the female headed households. Figure 3A plots the event-year coefficients from the estimation of equation (3) on whether the head was employed last year. The figure shows an absence of pre-trends, and shows a sharp turn downward after FSP is introduced. The estimates with and without controls for policy endogeneity are very similar. Figure 3B repeats the exercise with annual hours worked by the head. 
Again there is no pre-trend in hours worked prior to the introduction of FSP. Immediately after the program is introduced, there is a discrete drop in hours worked, and the coefficients continue to be negative and relatively flat in the subsequent years.

These results show strong evidence that our county adoption of FSP is identifying the causal impact of the food stamp program. These figures show no trend in the outcome variables leading up to the program introduction and sharp changes in the outcome following county program introduction. In our prior work analyzing the impact of the FSP introduction on infant health (Almond, Hoynes and Schanzenbach 2010) we used county FSP caseload data to show that the food stamp programs seemed to ramp up quite quickly in the 1-2 years following program adoption. This is consistent with the outcome results in Figures 3A and 3B.

The remaining panels in Figure 3 shows impacts of food stamp introduction on head's annual earnings and the log of family income. Figure 3C, which reports estimates on head's earnings, may show a small downward trend prior to the introduction of FSP, but there is still a sharp drop in earnings immediately following the introduction of the program. Finally, Figure 3D, which reports estimates for (log) family income, the impact of FSP here is - consistent with the small and imprecise coefficients in the earlier tables - not sharp and does not imply an important impact of FSP on total income.

\section{d. Specification check using Decennial Census}

As a final robustness check, we estimate the impact of FSP program introduction on labor supply using public use decennial Census data from the county-level aggregate files-known as the STF files. Here, we are limited to the variables and samples that have been pre-tabulated by the Census. We are able to estimate models for female labor force participation rates, male labor force participation rates, labor force participation rates for women with a child under age six, and the 
fraction of families with income below 10,000 (in real 1979 dollars). ${ }^{24}$ We pool county outcomes from the 1960, 1970 and 1980 Censuses and estimate models similar to those presented above, with decade fixed effects replacing the year fixed effects. The regressions are weighted using county population and the standard errors are clustered on county. The results are presented in Table 6with panel A reporting estimates for all persons and panel B reporting estimates for nonwhites (for variables that are available). ${ }^{25}$

It is important to note that these treatment groups are broader than the targeted samples used in the PSID and there is no way to weight the treatment by group participation rate because the data are county wide averages. With that said, the results show a relatively statistically precise, small negative estimated work disincentive effect. For example, the estimate for males (females) shows that implementing a food stamp program leads to a statistically significant $0.003(0.002)$ decrease in the labor force participation rate compared to the mean value of $0.76(0.40)$. Using an average participation rate of 7.4, these imply TOT impacts on women of 2.7 percentage points (in italics in the table) or about 7 percent. For men, the TOT impacts are 4.1 percentage points or 5 percent. In addition, the probability that overall family cash income (not including food stamps) is less than $\$ 10,000$ per year (in 1979 dollars) increases by a statistically significant 1 to 3 percentage points.

\section{Discussion}

Overall, the evidence from the PSID and decennial Census is consistent with our theoretical predictions. We generally find that the introduction of the food stamp program leads to lower rates of employment and hours. The evidence is less clear for earnings and family income as our results never

\footnotetext{
${ }^{24}$ The labor force participation rates are defined for persons age 16 and over.

${ }^{25}$ The smallest geographic area identified in the census public use micro data is the county group, these are contiguous groups of counties with a combined population of 100,000 or more We estimated models using the 1970 and 1980 public use micro data IPUMS data where we aggregated the FSP treatment across all counties in the country group. Further, we had to combine county groups to accommodate the changing county group boundaries between the 1970 and 1980 Census. In the end, this aggregation was substantial and the results had very low power. The results are available on request.
} 
approach statistical significance for these outcomes. The validity of the research design and estimates is confirmed by several additional results. First, the impacts are larger in subsamples with higher participation rates (e.g. female heads of household) and essentially zero for placebo groups such as highly educated married couples. Second, the event study results show that the policy introduction is unrelated to trends in the outcome variables, and labor supply sharply declines with the introduction of the program. Beyond the sign and statistical significance, however, what do our magnitudes tell us about the work disincentive effects of the food stamp program? How do our results compare to the literature?

Our preferred estimates use the pooled sample and the triple difference specification (Tables 4 and 5), as this takes advantage of the universal nature of the FSP program. However, the existing food stamp literature does not provide any estimates for comparison. As a check and to gauge the magnitude of the expected labor supply effects of the food stamp program, we simulated the impact of the program on annual hours worked in our PSID sample using estimated labor supply elasticities from the Negative Income Tax experiments (Robins and West 1983). The simulations for the full nonelderly sample predicted a 20-24 hour reduction in annual hours, which scaled up by the group FS participation rate implies about a 300 hour reduction in hours for participating households. This is quite similar to our (insignificant) estimated reduction in Table 4. Overall, we take this as a useful exercise which corroborates our estimates of modest work incentive effects in the food stamp program in the full sample. ${ }^{26}$

In the female headed household subsamples where we find our largest and most robust estimates, there is more scope to compare our results to the literature. We focus on the results for

\footnotetext{
${ }^{26}$ More specifically, we assign the compensated wage and income effects based on family type (female headed households are assigned the effects for "single females" and all male headed singles/families are assigned the effects for "husbands"). We assign maximum food stamp benefits and the food stamp breakeven income level by family size using the 1975 food stamp parameters in Table 2.2 from MacDonald (1977). The change in net wages is -0.3 reflecting the food stamp benefit reduction rate. We assume no nonlinear response to the implementation of food stamps and therefore simulate the change in hours for those families with head's earnings below the food stamps breakeven point. Full results of the simulation are available on request.
} 
annual hours, since that is the measure used in the literature. The Table 4 results show an increase in hours of 183-238 for all female heads, implying a TOT impact of 500-600 hours per year (or more than a 50 percent reduction). This is considerably larger than the Fraker and Moffitt (1988) results, whose structural model results indicate that food stamp participants reduce their work effort by less than 100 hours per year. It is also instructive to compare our results to the related literature examining the impacts of the AFDC program on labor supply. As summarize above in Section II, AFDC is estimated to reduce labor supply (annual hours) among program participants by 10 to 50 percent (546 hour reduction reported in Moffitt 1983). Our estimates for female headed households are on the high end of this range. At the same time we would have expected the FSP to yield smaller impacts than AFDC given the programs lower benefit reduction rate and lower guarantee.

\section{Conclusion}

In this paper we present evidence on the work incentive effects of food stamps, the largest cash or near-cash transfer program in the safety net. This paper provides an important contribution to the literature on work incentives of social welfare programs, and is the first paper on employment effects of the food stamp program that uses a quasi-experimental research design. The impacts of food stamps on work behavior have been difficult for researchers to isolate because there is little cross-state or over-time program variation to exploit. Here we use county variation in the adoption of the program between 1963 and 1975 to identify the impact of food stamps. Using the PSID, we find modest reductions overall in employment rates and hours worked, and larger reductions among female headed households. Our results suggest a larger work disincentive effect of FSP for female heads than had previously been concluded in the literature.

Even though there have been changes in the population of the United States, in the labor force attachment of women, and some of the parameters of FSP have changed, these results are still 
relevant for today's policy debates. To date, there is little credible evidence on the impact of FSP on work behavior. Understanding the incentives in FSP is important since such a large fraction of Americans rely on FSP, and it is one of the few remaining safety net programs that does not have a substantial work requirement component 


\section{References}

Acemoglu, Daron, David Autor and David Lyle. 2004. "Women War and Wages: The Impact of Female Labor Supply on the Wage Structure at Mid-Century." Journal of Political Economy, 112(3), June, $497-551$.

Almond, Douglas, Hilary W. Hoynes and Diane Whitmore Schanzenbach (Forthcoming). "The Impact of the Food Stamp Program on Infant Outcomes," Review of Economics and Statistics.

Berry, Jeffrey M. (1984). Feeding Hungry People: Rulemaking in the Food Stamp Program. New Brunswick, NJ: Rutgers University Press.

Bleakley, Hoyt (2007). "Disease and Development: Evidence from Hookworm Eradication in the American South," Quarterly Journal of Economics 122(1): 73-117.

Burtless, Gary and Jerry Hausman (1978). "The Effect of Taxation on Labor Supply: Evaluating the Gary Negative Income Tax Experiment,” Journal of Political Economy 86(6), pp. 1103-30.

Cascio, Elizabeth, Nora Gordon, Ethan Lewis, and Sarah Reber (2006). "Fiscal Responses to the Introduction of Title I."

Citizens’ Board of Inquiry (1968). Hunger, U.S.A. Boston: Beacon Press.

Currie, Janet (2003). "U.S. Food and Nutrition Programs," in Means-Tested Transfer Programs in the United States, Robert Moffitt (ed.). Chicago: University of Chicago Press.

Eissa, Nada and Hilary W. Hoynes (2006). "The Hours of Work Response of Married Couples: Taxes and the Earned Income Tax Credit," in Tax Policy and Labor Market Performance, Jonas Agell and Peter Birch Sørensen, eds. MIT Press, 2006.

Finklestein, Amy and Robin McKnight (2008) "What Did Medicare Do? The Initial Impact of Medicare on Mortality and Out of Pocket Medical Spending" Journal of Public Economics 92 (2008): 1644-1669.

Fraker, Thomas and Robert Moffitt (1988). "The Effect of Food Stamps on Labor Supply: A Bivariate Selection Model," Journal of Public Economics, February.

Hagstrom, Paul (1996). "The Food Stamp Participation and Labor Supply of Married Couples: An Empirical Analysis of Joint Decisions." Journal of Human Resources 31(2):383-403.

Hausman, Jerry (1980). "The Effects of Wages, Taxes and Fixed Costs on Women's Labor Force Participation," Journal of Public Economics, 14(2), pp.161-94.

Hausman, Jerry (1981). "Labor Supply," in How taxes affect economic behavior. Edited by henry Aaron and Joseph Pechman. Washington, D.C.: Brookings Institution, pp. 27-72. 
Hoynes, Hilary W. (1996). "Welfare Transfers in Two-Parent Families: Labor Supply and Welfare Participation Under the AFDC-UP Program," Econometrica, Volume 64, Number 2, pages 295-332.

Hoynes, Hilary W. (1997). “Work, Welfare, and Family Structure: What Have We Learned?" in Alan J. Auerbach, ed., Fiscal Policy: Lessons from Economic Research.

Hoynes, Hilary W. and Diane Whitmore Schanzenbach (2009). "Consumption Responses to In-Kind Transfers: Evidence from the Introduction of the Food Stamp Program.” American Economic Journal - Applied Economics 1(4): 109-39.

Johnson, Lyndon B. (1964). Remarks Upon Signing the Food Stamp Act. Available at: http://www.presidency.ucsb.edu/ws/index.php?pid=26472

Keane, M. and R. Moffitt (1998). "A Structural Model of Multiple Welfare Program Participation and Labor Supply.” International Economic Review, 39:3, 553-589.

Kotz, Nick (1969). Let them Eat Promises: The Politics of Hunger in America. New York: Doubleday.

Ludwig, Jens and Douglas Miller (2007) "Does Head Start improve children's outcomes? Evidence from a regression discontinuity design." Quarterly Journal of Economics 122(1): 159-208.

Moffitt, Robert (1983). “An economic model of welfare stigma.” American Economic Review 73(5):1023-1035.

Moffitt, Robert (1992). "Incentive Effects of the U.S. Welfare System: A Review.” Journal of Economic Literature 30(1):1-61.

Moffitt, Robert (2002). "Welfare Programs and Labor Supply.” In Alan J. Auerbach and Martin Feldstein, eds., Handbook of Public Economics. Amsterdam: North Holland.

Ohls, James and Harold Beebout (1993). The Food Stamp Program: Design Tradeoffs, Policy and Impacts. Washington: Urban Institute Press.

Robins, Philip and Richard West (1983) "Labor Supply Response." In Final Report of the Seattle/Denver Income Maintenance Experiment, edited by SRI International. Vol 1:pp91-198. Washington DC: US GPO.

U.S. Bureau of Economic Analysis (2007). "Regional Economic Accounts," http://www.bea.gov/bea/regional/reis/

U.S. Department of Agriculture (various years). "Food Stamp Program, Year-End Participation and Bonus Coupons Issues," Technical report, Food and Nutrition Service. 
Figure 1: Cumulative Percent of Counties with Food Stamp Program, 1960-1975

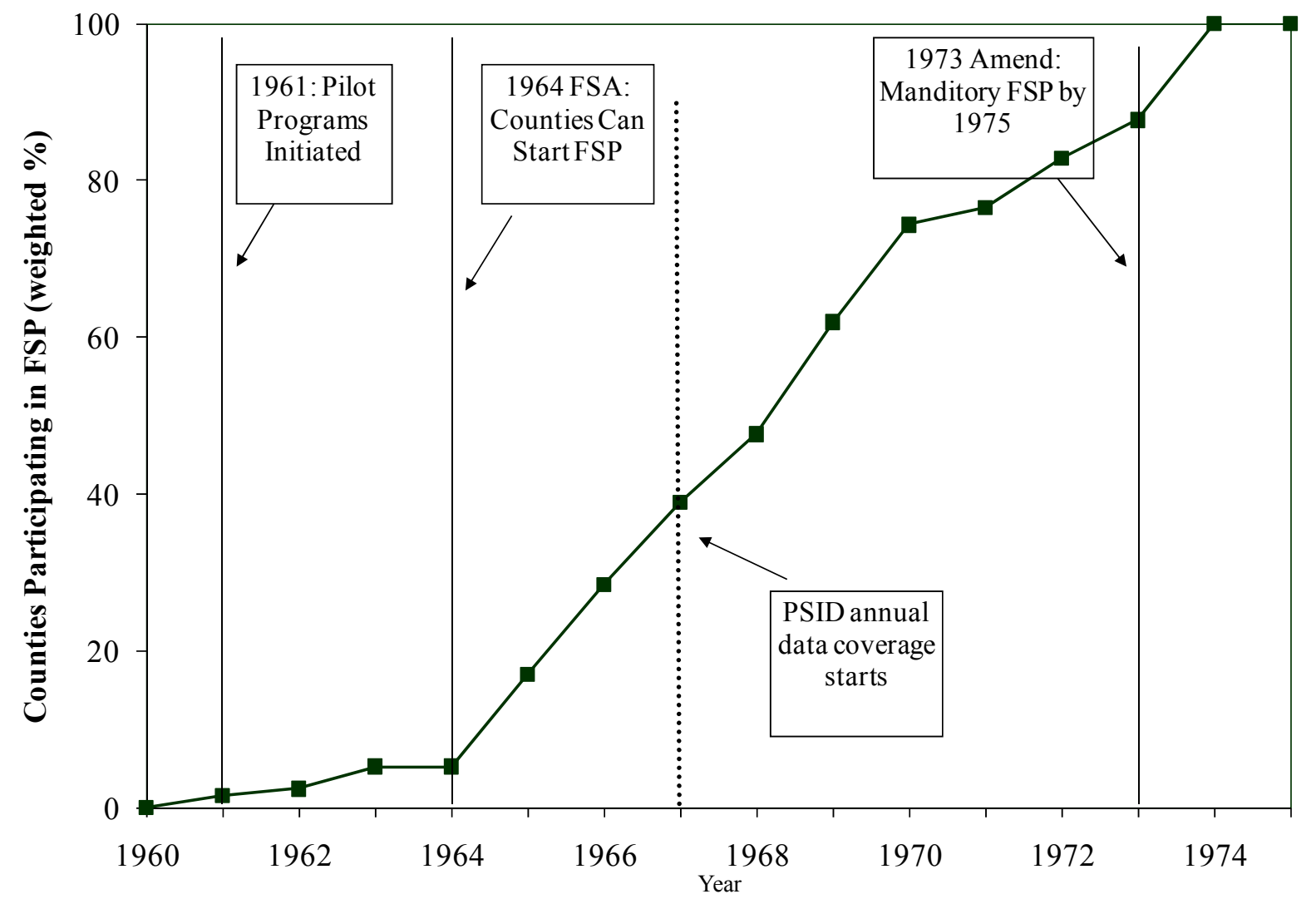

Source: Author's tabulations of county FSP start dates. Counties are weighted by their 1960 populations. 
Figure 2a: Income-Leisure Diagram Before Food Stamps

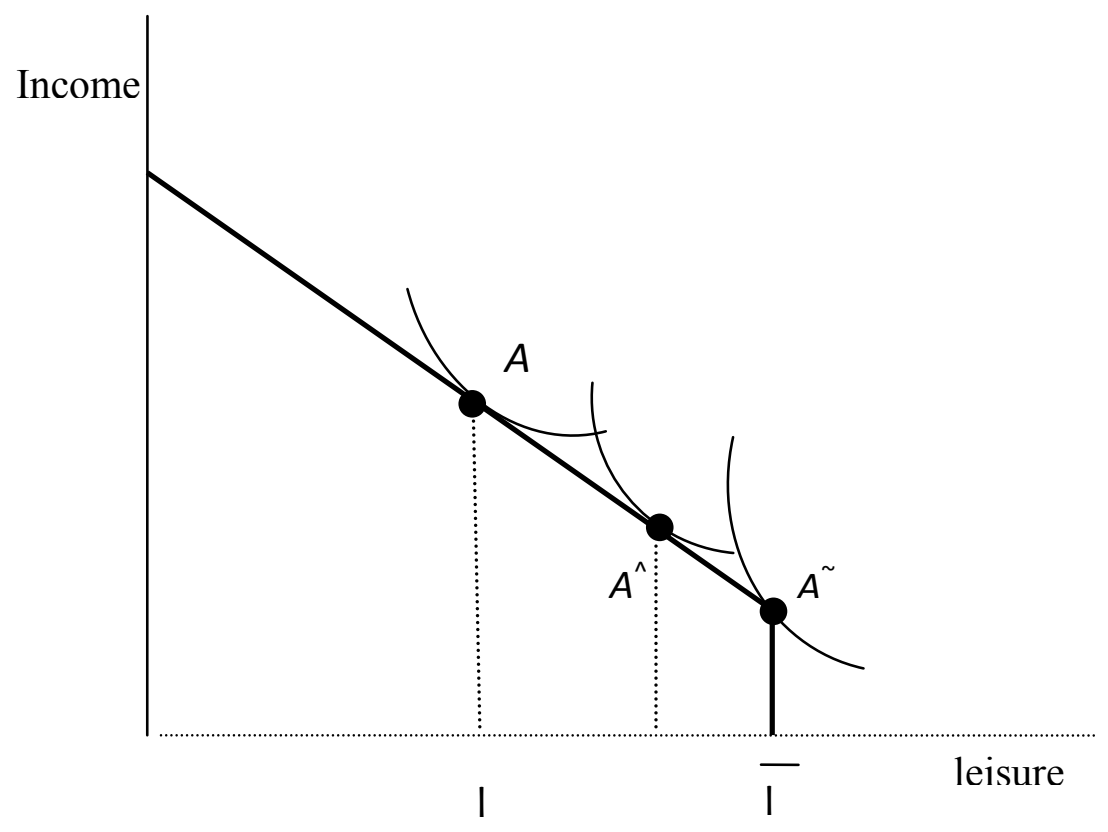

Figure 2b: Income-Leisure Diagram After Food Stamps

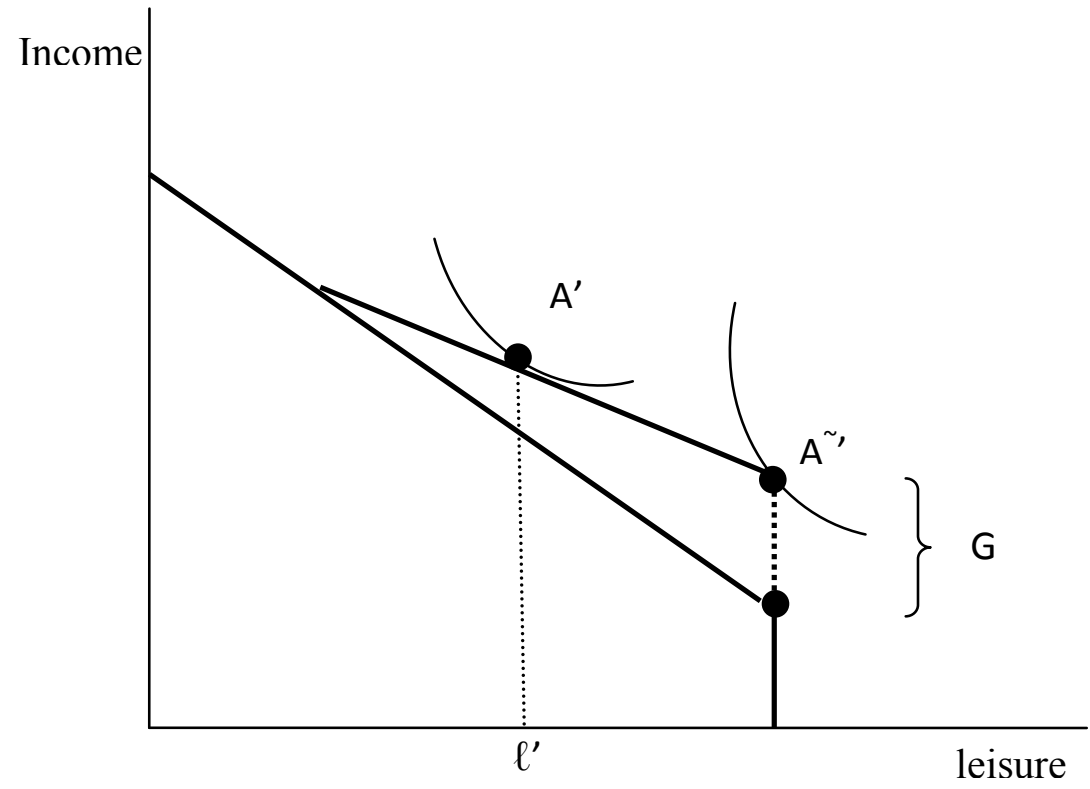


Figure 3a: Event Study Estimates of Impact of FSP on Head Any Work Last Year Female headed households with children only

Head work (any last year)

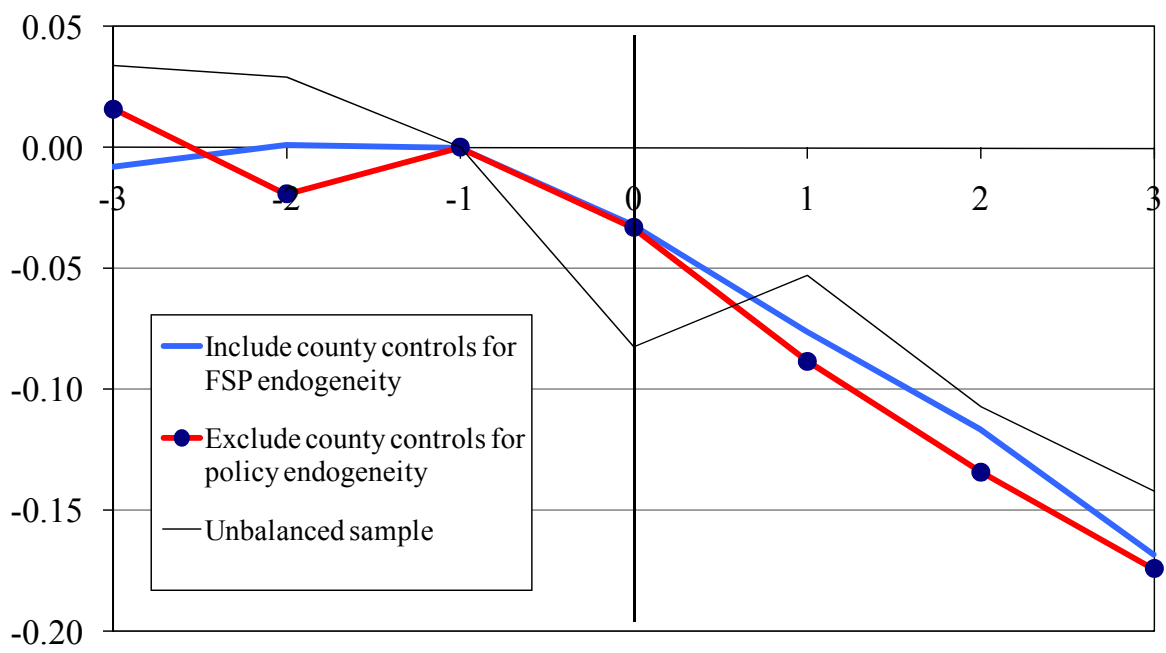

event time in years

Figure 3b: Event Study Estimates of Impact of FSP on Head Annual Hours Female headed households with children only

Head annual hours

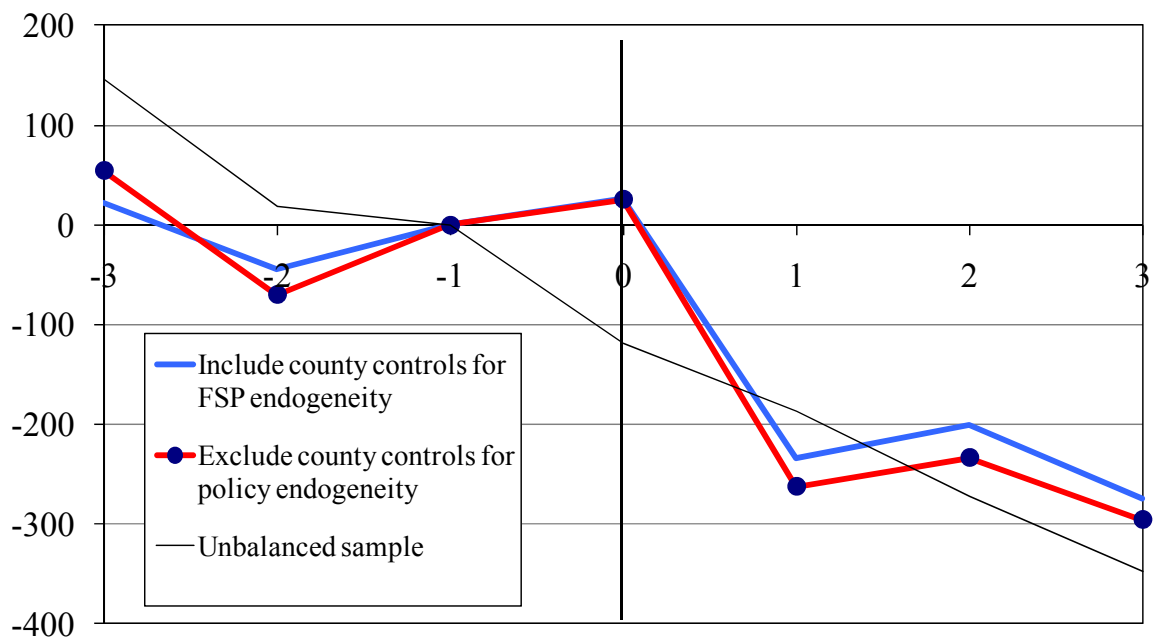

event time in years 
Figure 3c: Event Study Estimates of Impact of FSP on Head Earnings

Female headed households with children only

\section{Head earnings}

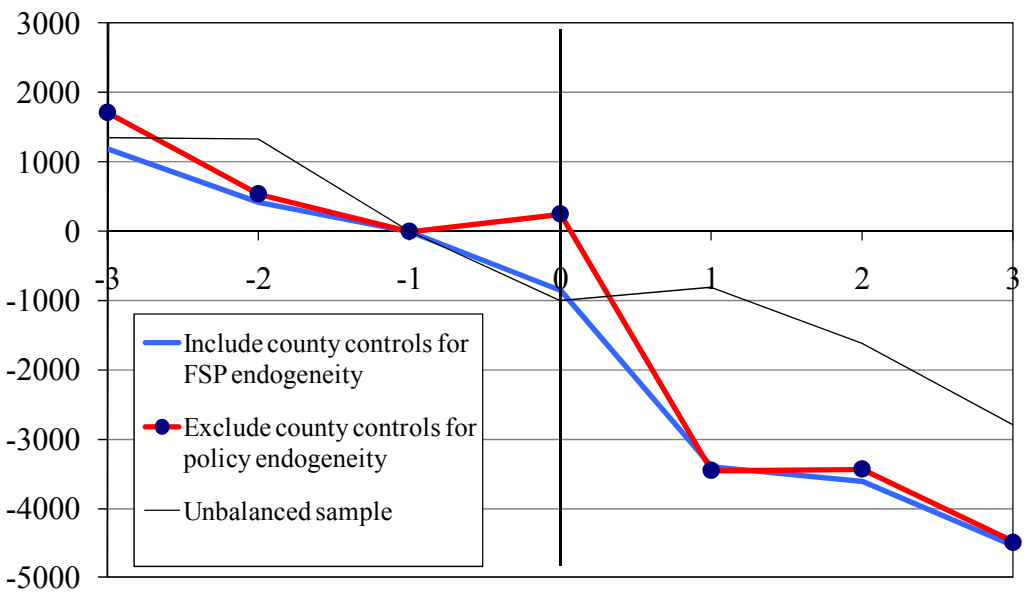

event time in years

Figure 3d: Event Study Estimates of Impact of FSP on Head Earnings Female headed households with children only

\section{In( Family Income)}

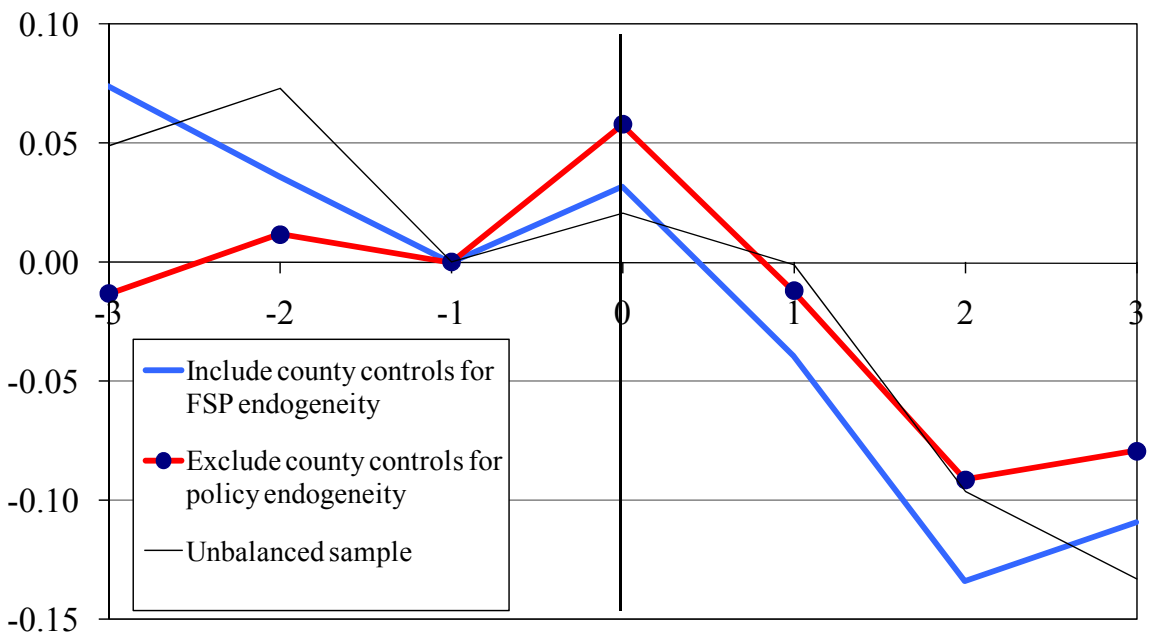

event time in years

Notes: Each figure plots coefficients from an event-study analysis. Coefficients are defined as years relative to the year the Food Stamp Program is implemented in the county. The sample is limited to female-headed households with children. The balanced sample lines include information on a county only if there are at least 3 years pre- and post-implementation data. The specification includes controls for demographics, unrestricted fixed effects for county and year, county per capita transfers, state-specific linear time trends, and 1960 county characteristics interacted with linear time. 
Table 1: Impacts of Food Stamp Introduction on Labor Supply and Family Income, by Group

\begin{tabular}{|c|c|c|c|c|c|c|c|c|}
\hline & \multicolumn{2}{|c|}{ All nonelderly households } & \multicolumn{2}{|c|}{ Nonelderly, Head Educ $<=12$} & \multicolumn{2}{|c|}{ Female Heads } & \multicolumn{2}{|c|}{$\begin{array}{c}\text { Nonwhite } \\
\text { Female Heads }\end{array}$} \\
\hline & $(1)$ & $(2)$ & (3) & $(4)$ & $(5)$ & (6) & $(7)$ & $(8)$ \\
\hline \multicolumn{9}{|l|}{ A. Any Food Stamps $=1$} \\
\hline$\overline{\text { County FSP Implemented }}$ & $\begin{array}{c}0.028 \\
(0.007)^{* * *}\end{array}$ & $\begin{array}{c}0.028 \\
(0.009)^{* * *}\end{array}$ & $\begin{array}{c}0.043 \\
(0.009)^{* * *}\end{array}$ & $\begin{array}{c}0.048 \\
(0.010)^{* * *}\end{array}$ & $\begin{array}{c}0.223 \\
(0.047)^{* * *}\end{array}$ & $\begin{array}{c}0.193 \\
(0.045)^{* * *}\end{array}$ & $\begin{array}{c}0.377 \\
(0.075)^{* * *}\end{array}$ & $\begin{array}{c}0.247 \\
(0.058)^{* * *}\end{array}$ \\
\hline Number of Observations & 43,673 & 43,673 & 34,060 & 34,060 & 5,681 & 6,256 & 4,264 & 4,688 \\
\hline \multicolumn{9}{|l|}{ B. Head Any Work $=1$} \\
\hline County FSP Implemented & $\begin{array}{c}0.000 \\
(0.005)\end{array}$ & $\begin{array}{c}0.010 \\
(0.008)\end{array}$ & $\begin{array}{c}0.006 \\
(0.007)\end{array}$ & $\begin{array}{c}0.019 \\
(0.010)^{*}\end{array}$ & $\begin{array}{l}-0.043 \\
(0.037)\end{array}$ & $\begin{array}{l}-0.040 \\
(0.050)\end{array}$ & $\begin{array}{l}-0.048 \\
(0.041)\end{array}$ & $\begin{array}{c}-0.097 \\
(0.055)^{*}\end{array}$ \\
\hline Dependent variable mean & 0.926 & 0.926 & 0.904 & 0.904 & 0.707 & 0.071 & 0.605 & 0.615 \\
\hline \multicolumn{9}{|l|}{ C. Head Annual hours } \\
\hline$\overline{\text { County FSP Implemented }}$ & $\begin{array}{c}8 \\
(20)\end{array}$ & $\begin{array}{c}34 \\
(25)\end{array}$ & $\begin{array}{l}16 \\
(24)\end{array}$ & $\begin{array}{c}36 \\
(31)\end{array}$ & $\begin{array}{c}-183 \\
(77)^{* *}\end{array}$ & $\begin{array}{l}-238 \\
(97)^{* *}\end{array}$ & $\begin{array}{l}-158 \\
(74)^{* *}\end{array}$ & $\begin{array}{c}-282 \\
(88)^{* * *}\end{array}$ \\
\hline Dependent variable mean & 1947 & 1947 & 1879 & 1879 & 1068 & 1068 & 864 & 864 \\
\hline \multicolumn{9}{|l|}{ D. Head Annual Earnings } \\
\hline County FSP Implemented & $\begin{array}{c}270 \\
(729)\end{array}$ & $\begin{array}{l}-445 \\
(960)\end{array}$ & $\begin{array}{l}-32 \\
(643)\end{array}$ & $\begin{array}{l}-219 \\
(966)\end{array}$ & $\begin{array}{c}-533 \\
(1112)\end{array}$ & $\begin{array}{l}-1065 \\
(1329)\end{array}$ & $\begin{array}{l}-1193 \\
(986)\end{array}$ & $\begin{array}{c}-3169 \\
(1317)^{* *}\end{array}$ \\
\hline Dependent variable mean & 41742 & 41742.00 & 34600 & 34600 & 14194 & 14194 & 10022 & 10022.00 \\
\hline \multicolumn{9}{|l|}{ E. Log(Family Income) } \\
\hline County FSP Implemented & $\begin{array}{c}0.004 \\
(0.015) \\
\end{array}$ & $\begin{array}{l}-0.003 \\
(0.020) \\
\end{array}$ & $\begin{array}{l}-0.001 \\
(0.017) \\
\end{array}$ & $\begin{array}{l}-0.008 \\
(0.023) \\
\end{array}$ & $\begin{array}{l}-0.046 \\
(0.051) \\
\end{array}$ & $\begin{array}{l}-0.096 \\
(0.060) \\
\end{array}$ & $\begin{array}{r}-0.037 \\
(0.064) \\
\end{array}$ & $\begin{array}{c}0.014 \\
(0.086) \\
\end{array}$ \\
\hline Number of Observations & 48,168 & 48,148 & 37,474 & 37,447 & 7,280 & 6,890 & 5,464 & 5,175 \\
\hline 1960 Cty Vars * Linear Time & $\mathrm{X}$ & $\mathrm{X}$ & $\mathrm{X}$ & $\mathrm{X}$ & $\mathrm{X}$ & $\mathrm{X}$ & $\mathrm{X}$ & $\mathrm{X}$ \\
\hline Year and County Fixed Effects & $\mathrm{X}$ & $\mathrm{X}$ & $\mathrm{X}$ & $\mathrm{X}$ & $\mathrm{X}$ & $\mathrm{X}$ & $\mathrm{X}$ & $\mathrm{X}$ \\
\hline Per Capita Cty Transfers & $\mathrm{X}$ & $\mathrm{X}$ & $\mathrm{X}$ & $\mathrm{X}$ & $\mathrm{X}$ & $\mathrm{X}$ & $\mathrm{X}$ & $\mathrm{X}$ \\
\hline State x Linear Time & $\mathrm{X}$ & $\mathrm{X}$ & $\mathrm{X}$ & $\mathrm{X}$ & $\mathrm{X}$ & $\mathrm{X}$ & $\mathrm{X}$ & $X$ \\
\hline State $\mathrm{x}$ Year FE & & $\mathrm{X}$ & & $\mathrm{X}$ & & $\mathrm{X}$ & & $\mathrm{X}$ \\
\hline
\end{tabular}

Notes: Each parameter is from a separate regression of the outcome variable on a dummy variable equal to 1 if the county-year observation had a food stamp program in place by January of that year. The sample includes non-elderly PSID families using interview years 1968-1978. Observations from Alaska are dropped because of missing data on food stamp program start dates. All outcome

variables correspond to annual measures taken as of the interview (in spring of the interview year). Demographic controls include dummies for education, number of children, number of adults, race, urban location and state unemployment rate. 1960 county variables include log of population, percent of land in farming, percent of population black, urban, age $<5$, age $>65$ and with income less than $\$ 3,000$, each interacted with a linear time trend. Per capita county transfer income comes from the BEA REIS and includes measures for public assistance (AFDC, General Assistance), medical care (Medicare, Medicaid, military), and retirement and disability benefits. Estimates are weighted using the PSID weight and clustered on county. Standard errors are in parenthesis and ***, **, and * indicate that the estimates are statistically significant at the $1 \%, 5 \%$ and $10 \%$ levels, respectively. 
Table 2: Impacts of Food Stamp Introduction on Labor Supply and Family Income, Married-Couple Households Only

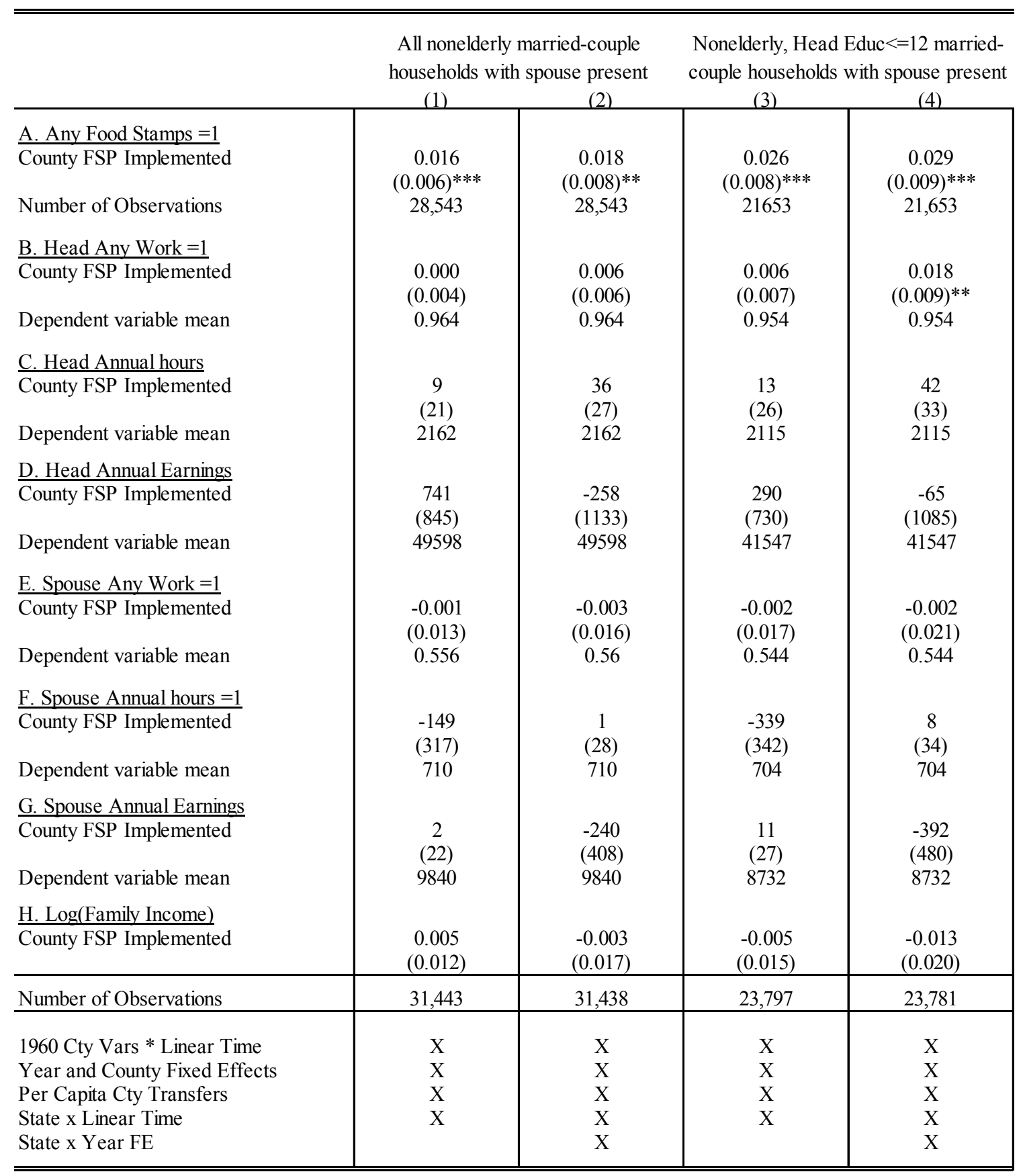

Notes: Each parameter is from a separate regression of the outcome variable on a dummy variable equal to 1 if the county-year observation had a food stamp program in place by January of that year. The sample includes married, non-elderly PSID families using interview years 1968-1978. Observations from Alaska are dropped because of missing data on food stamp program start dates. All outcome variables correspond to annual measures taken as of the interview (in spring of the interview year). Demographic controls include dummies for education, number of children, number of adults, race, urban location and state unemployment rate. 1960 county variables include log of population, percent of land in farming, percent of population black, urban, age $<5$, age $>65$ and with income less than $\$ 3,000$, each interacted with a linear time trend. Per capita county transfer income comes from the BEA REIS and includes measures for public assistance (AFDC, General Assistance), medical care (Medicare, Medicaid, military), and retirement and disability benefits. Estimates are weighted using the PSID weight and clustered on county. Standard errors are in parenthesis and ${ }^{* *}, * *$, and $*$ indicate that the estimates are statistically significant at the $1 \%, 5 \%$ and $10 \%$ levels, respectively. 
Table 3: Impacts of Food Stamp Introduction on Labor Supply and Family Income, Placebo Samples

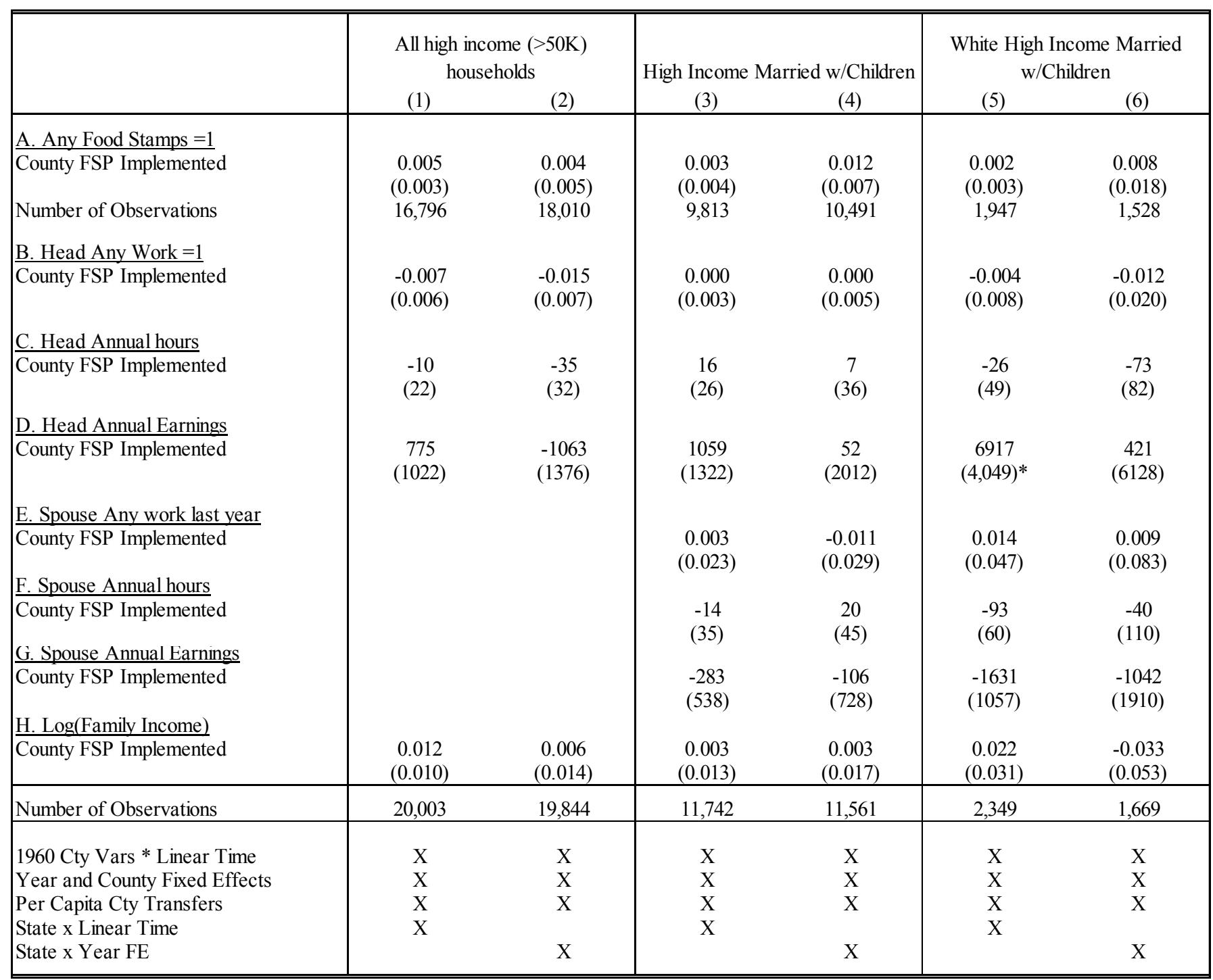

Notes: Each parameter is from a separate regression of the outcome variable on a dummy variable equal to 1 if the county-year observation had a food stamp program in place by January of that year. The sample includes non-elderly PSID families using interview years 1968-1978.

Observations from Alaska are dropped because of missing data on food stamp program start dates. All outcome variables correspond to annual measures taken as of the interview (in spring of the interview year). Demographic controls include dummies for education, number of children, number of adults, race, urban location and state unemployment rate. 1960 county variables include log of population, percent of land in farming, percent of population black, urban, age $<5$, age $>65$ and with income less than $\$ 3,000$, each interacted with a linear time trend. Per capita county transfer income comes from the BEA REIS and includes measures for public assistance (AFDC, General Assistance), medical care (Medicare, Medicaid, military), and retirement and disability benefits. Estimates are weighted using the PSID weight and clustered on county. Standard errors are in parenthesis and $*^{* *}, *^{*}$, and $*$ indicate that the estimates are statistically significant at the $1 \%, 5 \%$ and $10 \%$ levels, respectively. 
Table 4: Impact of Food Stamp Introduction on Labor Supply and Family Income Triple Difference Estimates for Nonelderly Sample

(1)

-0.266
$(0.081)^{* * *}$
0.019
$(0.007)^{* * *}$

$-281$

County FSP Implemented

Head Annual hours

County FSP Implemented x Pg

(2)

(3)

$\underline{\text { Head Any work last year }}$

County FSP Implemented x Pg

County FSP Implemented

Head Annual Earnings

County FSP Implemented x Pg

County FSP Implemented

$\underline{\log \text { (Family Income) }}$

County FSP Implemented x Pg

County FSP Implemented
(183)

$\begin{array}{ccc}-6885 & -6929 & -4673 \\ (6142) & (6168) & (5648) \\ 830 & -22 & 694 \\ (906) & (1099) & (889)\end{array}$

$-0.062$

$-0.137$

$(0.124)$

$-0.058$

(0.111)

0.005

(0.112)

0.013

(0.021)

(0.016)

$(0.016)$
$-268$

(168)

(23)
48,148

$\mathrm{X}$

$\mathrm{X}$

$\mathrm{X}$

$\mathrm{X}$

$\mathrm{X}$

$\mathrm{X}$
48,168

$\mathrm{X}$

$\mathrm{X}$

$\mathrm{X}$

$\mathrm{X}$

$\mathrm{X}$

$\mathrm{X}$

X

State $\mathrm{x}$ year fe

Pg x Other Covariates (except area fixed effects)

Notes: Each parameter is from a separate regression of the outcome variable on the food stamp implementation dummy multiplied by a group food stamp participation rate. The food stamp implementation dummy equals one if the county-year observation had a food stamp program in place by January of that year. The group food stamp participation rate is calculated for each education-race-marital status-presence of children cell using the 1976-78 PSID. The sample includes all years 1968-78 and excludes observations from Alaska. For details on this sample selection, see text. All outcome variables correspond to annual measures taken as of the interview (in spring of the interview year). Demographic controls include dummies for education, number of children, number of adults, race, urban location and state unemployment rate. 1960 county variables include log of population, percent of land in farming, percent of population black, urban, age $<5$, age $>65$ and with income less than $\$ 3,000$, each interacted with a linear time trend. Per capita county transfer income comes from the BEA REIS and includes measures for public assistance (AFDC, General Assistance), medical care (Medicare, Medicaid, military), and retirement and disability benefits. Estimates are weighted using the PSID weight and clustered on county. Standard errors are in parenthesis and ${ }^{* * *},{ }^{*}$, and * indicate that the estimates are statistically significant at the $1 \%, 5 \%$ and $10 \%$ levels, respectively. 
Table 5: Impact of Food Stamp Introduction on Labor Supply and Family Income Triple Difference Estimates for Nonelderly, Married-Couple Sample

\begin{tabular}{|c|c|c|c|}
\hline & (1) & (2) & (3) \\
\hline \multicolumn{4}{|l|}{ Head Any work last year } \\
\hline County FSP Implemented x Pg & $\begin{array}{r}-0.107 \\
(0.086)\end{array}$ & $\begin{array}{c}-0.111 \\
(0.087)\end{array}$ & $\begin{array}{l}-0.106 \\
(0.073)\end{array}$ \\
\hline County FSP Implemented & $\begin{array}{c}0.005 \\
(0.005)\end{array}$ & $\begin{array}{c}0.012 \\
(0.007)^{*}\end{array}$ & $\begin{array}{c}0.005 \\
(0.005)\end{array}$ \\
\hline \multicolumn{4}{|l|}{ Head Annual hours } \\
\hline County FSP Implemented x Pg & $\begin{array}{l}-102 \\
(405)\end{array}$ & $\begin{array}{l}-120 \\
(416)\end{array}$ & $\begin{array}{l}-153 \\
(393)\end{array}$ \\
\hline County FSP Implemented & $\begin{array}{l}13 \\
(32)\end{array}$ & $\begin{array}{c}41 \\
(36)\end{array}$ & $\begin{array}{l}15 \\
(31)\end{array}$ \\
\hline \multicolumn{4}{|l|}{ Spouse Any work last year } \\
\hline County FSP Implemented x Pg & $\begin{array}{c}-0.163 \\
(0.284)\end{array}$ & $\begin{array}{r}-0.117 \\
(0.292)\end{array}$ & $\begin{array}{l}-0.071 \\
(0.259)\end{array}$ \\
\hline County FSP Implemented & $\begin{array}{l}0.009 \\
(0.02)\end{array}$ & $\begin{array}{c}0.004 \\
(0.024)\end{array}$ & $\begin{array}{l}0.004 \\
(0.02)\end{array}$ \\
\hline \multicolumn{4}{|l|}{ Spouse Annual hours } \\
\hline 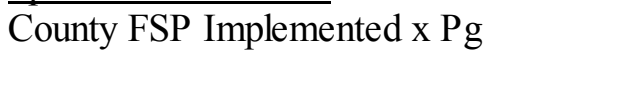 & $\begin{array}{l}-204 \\
(569)\end{array}$ & $\begin{array}{l}-154 \\
(584)\end{array}$ & $\begin{array}{c}-39 \\
(500)\end{array}$ \\
\hline County FSP Implemented & $\begin{array}{c}15 \\
(38)\end{array}$ & $\begin{array}{c}13 \\
-41\end{array}$ & $\begin{array}{c}6 \\
(34)\end{array}$ \\
\hline \multicolumn{4}{|l|}{$\underline{\log (\text { Family Income) }}$} \\
\hline County FSP Implemented x Pg & $\begin{array}{c}-0.241 \\
(0.315)\end{array}$ & $\begin{array}{r}-0.230 \\
(0.326)\end{array}$ & $\begin{array}{l}-0.199 \\
(0.302)\end{array}$ \\
\hline County FSP Implemented & $\begin{array}{c}0.019 \\
(0.021) \\
\end{array}$ & $\begin{array}{c}0.011 \\
(0.025) \\
\end{array}$ & $\begin{array}{c}0.017 \\
(0.020) \\
\end{array}$ \\
\hline Number of Observations & 31,443 & 31,438 & 31,443 \\
\hline 1960 Cty Vars * Linear Time & $\mathrm{X}$ & $\mathrm{X}$ & $\mathrm{X}$ \\
\hline Per Capita Cty Transfers & $\mathrm{X}$ & $\mathrm{X}$ & $\mathrm{X}$ \\
\hline Group Fixed Effects, Group * linear time & $\mathrm{X}$ & $\mathrm{X}$ & $\mathrm{X}$ \\
\hline Year Fixed Effects (main and x Pg) & $\mathrm{X}$ & $\mathrm{X}$ & $\mathrm{X}$ \\
\hline County Fixed Effects & $\mathrm{X}$ & $\mathrm{X}$ & $\mathrm{X}$ \\
\hline State $\mathrm{x}$ Linear Time & $X$ & & $\mathrm{X}$ \\
\hline State $\mathrm{x}$ year fe & & $\mathrm{X}$ & \\
\hline Pg x Other Covariates & & & $\mathrm{X}$ \\
\hline
\end{tabular}

Notes: Each parameter is from a separate regression of the outcome variable on the food stamp implementation dummy multiplied by a group food stamp participation rate. The food stamp implementation dummy equals one if the county-year observation had a food stamp program in place by January of that year. The group food stamp participation rate is calculated for each education-race-presence of children cell using the 1976-78 PSID. The sample includes all years 1968-78 and excludes observations from Alaska. The sample includes only married couples. For details on this sample selection, see text. All outcome variables correspond to annual measures taken as of the interview (in spring of the interview year). Demographic controls include dummies for education, number of children, number of adults, race, urban location and state unemployment rate. 1960 county variables include log of population, percent of land in farming, percent of population black, urban, age $<5$, age $>65$ and with income less than $\$ 3,000$, each interacted with a linear time trend. Per capita county transfer income comes from the BEA REIS and includes measures for public assistance (AFDC, General Assistance), medical care (Medicare, Medicaid, military), and retirement and disability benefits. Estimates are weighted using the PSID weight and clustered on county. Standard errors are in parenthesis and ***, **, and * indicate that the estimates are statistically significant at the $1 \%, 5 \%$ and $10 \%$ levels, respectively. 
Table 6: Impact of Food Stamp Introduction on Labor Supply and Family Income 1960, 1970, 1980 Census STF Analysis

\begin{tabular}{lcccc}
\hline & \multicolumn{2}{c}{ Labor Force Participation Rate } & \\
\cline { 2 - 3 } & $\begin{array}{c}\text { Females } 16 \text { and } \\
\text { over }\end{array}$ & $\begin{array}{c}\text { Males } 16 \text { and } \\
\text { over }\end{array}$ & $\begin{array}{c}\text { Females with } \\
\text { children<6 }\end{array}$ & $\begin{array}{c}\text { Family Income }< \\
\$ 10,000(1979 \$)\end{array}$ \\
& $(1)$ & $(2)$ & $(3)$ & $(4)$ \\
\hline A. All Races & & & & \\
County FSP Implemented & -0.002 & -0.003 & 0.004 & 0.009 \\
& $(0.001)^{*}$ & $(0.001)^{* *}$ & $(0.008)$ & $(0.002)^{* * *}$ \\
Treatment on Treated & -0.027 & -0.041 & 0.054 & 0.122 \\
Dependent variable mean & 0.396 & 0.762 & 0.337 & 0.238 \\
Number of Observations & 7,898 & 7,898 & 7,898 & 7,898 \\
B. Nonwhites & & & & \\
County FSP Implemented & 0.002 & -0.004 & $\mathrm{n} / \mathrm{a}$ & 0.027 \\
& $(0.004)$ & $(0.003)$ & & $(0.006)^{* * *}$ \\
Dependent variable mean & 0.457 & 0.703 & & 0.455 \\
Number of Observations & 7,443 & 7,321 & & 7,093 \\
\hline 1960 Cty Vars * decade fixed effects & $\mathrm{X}$ & $\mathrm{X}$ & $\mathrm{X}$ & $\mathrm{X}$ \\
Per capita county transfer payments & $\mathrm{X}$ & $\mathrm{X}$ & $\mathrm{X}$ & $\mathrm{X}$ \\
Decade fixed effects & $\mathrm{X}$ & $\mathrm{X}$ & $\mathrm{X}$ & $\mathrm{X}$ \\
County fixed effects & $\mathrm{X}$ & $\mathrm{X}$ & $\mathrm{X}$ & $\mathrm{X}$ \\
\hline \hline
\end{tabular}

Notes: Each parameter is from a separate regression of the outcome variable on a dummy variable equal to 1 if the county-year observation had a food stamp program in place in that year. Data are from 1960-1980 Census county-level STF files. Counties in Alaska are dropped because of missing data on food stamp program start dates. Demographic controls include dummies for education, number of children, number of adults, race, urban location and state unemployment rate. 1960 county variables include log of population, percent of land in farming, percent of population black, urban, age $<5$, age $>65$ and with income less than $\$ 3,000$, each interacted with a linear time trend. Per capita county transfer income comes from the BEA REIS and includes measures for public assistance (AFDC, General Assistance), medical care (Medicare, Medicaid, military), and retirement and disability benefits. Estimates are weighted using the PSID weight and clustered on county. Standard errors are in parenthesis and $* * * * *$, and $*$ indicate that the estimates are statistically significant at the $1 \%, 5 \%$ and $10 \%$ levels, respectively. 
Appendix Table 1: Determinants of County Level Food Stamp Program Start Date Analysis Using the 1960 City and County Data Book

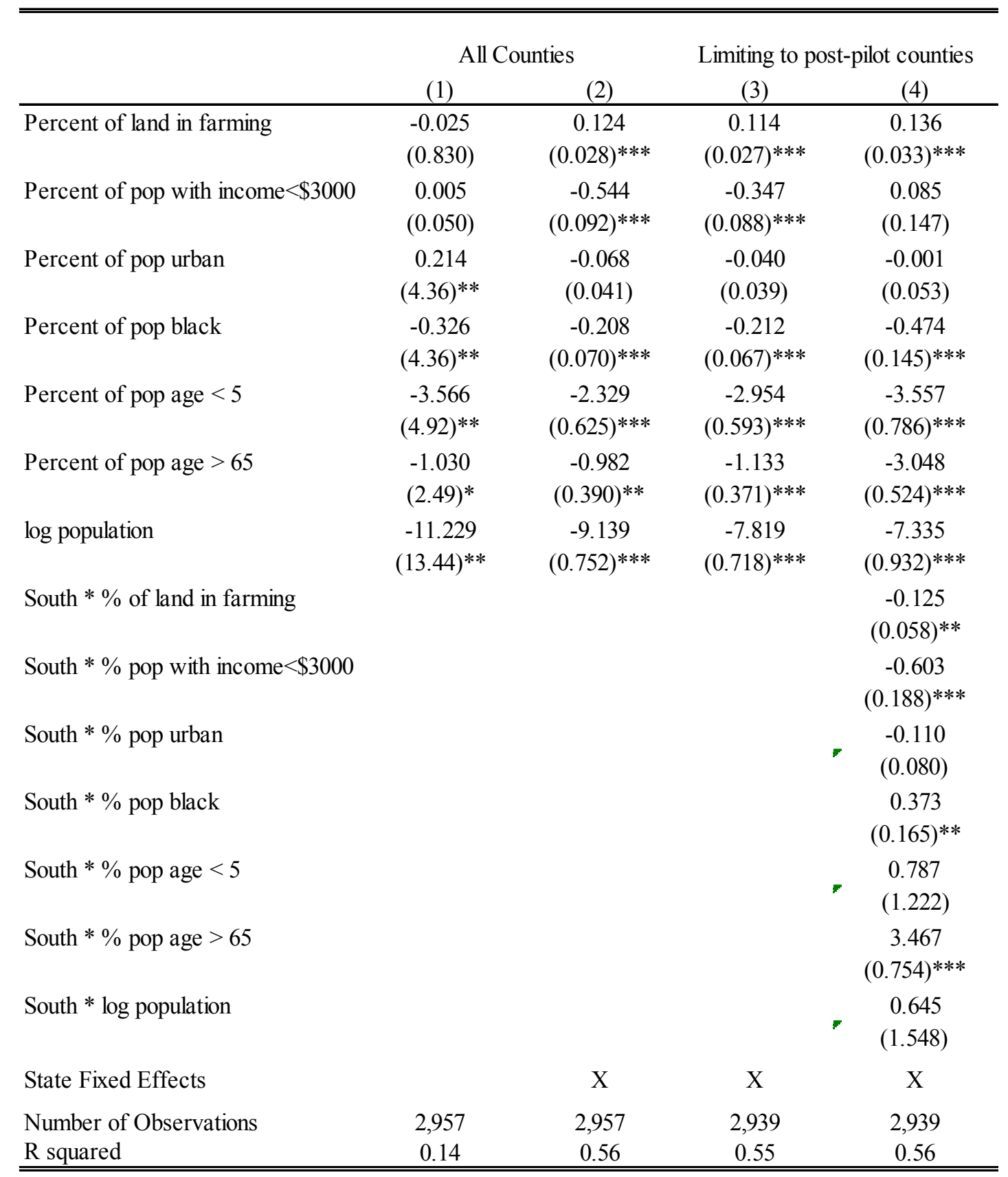

Notes: The data are at the county level and the dependent variable is equal to the calendar month (normed to 1 in January 1961) that the county began offering the Food Stamp Program. The control variables come from the City and County Data Book for 1960. Alaska counties are dropped due to missing data on the food stamp program. Very small counties (with population less than 1,000) are dropped because of missing data on some control variables. A small number of counties are dropped because the variable percent of land in farming exceeds 100 percent. Estimates are weighted using the 1960 county population. 
Appendix Table 2: Food Stamp Participation Rates by Demographic Group

\begin{tabular}{|c|c|c|c|c|}
\hline & \multirow[b]{2}{*}{ All } & \multicolumn{3}{|c|}{$\frac{\text { Education Group }}{\text { High School }}$} \\
\hline & & Less than HS & Grad & More than HS \\
\hline \multicolumn{5}{|l|}{ A. All Races } \\
\hline All family types & 0.08 & 0.14 & 0.06 & 0.02 \\
\hline Single with children & 0.32 & 0.46 & 0.23 & 0.15 \\
\hline Married with children & 0.07 & 0.14 & 0.06 & 0.01 \\
\hline Single, no children & 0.07 & 0.14 & 0.05 & 0.03 \\
\hline Married, no children & 0.02 & 0.04 & 0.01 & 0.01 \\
\hline Single, no children elderly & 0.07 & 0.10 & 0.03 & 0.01 \\
\hline Married, no children elderly & 0.03 & 0.05 & 0.00 & 0.00 \\
\hline \multicolumn{5}{|l|}{ B. White } \\
\hline All family types & 0.05 & 0.10 & 0.04 & 0.02 \\
\hline Single with children & 0.22 & 0.38 & 0.14 & 0.07 \\
\hline Married with children & 0.05 & 0.12 & 0.05 & 0.01 \\
\hline Single, no children & 0.05 & 0.11 & 0.04 & 0.03 \\
\hline Married, no children & 0.01 & 0.03 & 0.00 & 0.01 \\
\hline Single, no children elderly & 0.05 & 0.07 & 0.02 & 0.01 \\
\hline Married, no children elderly & 0.02 & 0.04 & 0.00 & 0.00 \\
\hline \multicolumn{5}{|l|}{ C. Nonwhite } \\
\hline All family types & 0.22 & 0.28 & 0.18 & 0.09 \\
\hline Single with children & 0.51 & 0.56 & 0.44 & 0.43 \\
\hline Married with children & 0.16 & 0.22 & 0.14 & 0.03 \\
\hline Single, no children & 0.13 & 0.20 & 0.09 & 0.04 \\
\hline Married, no children & 0.06 & 0.10 & 0.02 & 0.02 \\
\hline Single, no children elderly & 0.24 & 0.25 & 0.11 & 0.00 \\
\hline Married, no children elderly & 0.10 & 0.13 & 0.00 & 0.00 \\
\hline
\end{tabular}

Notes: Weighted means of food stamp participation rates using families in the 1976-1978 Panel Study of Income Dynamics. These years were chosen because by 1976 all counties had implemented food stamp programs yet it was before the elimination of the purchase requirement in 1979. 
Appendix Table 3: Descriptive Statistics for PSID Samples

\begin{tabular}{|c|c|c|c|c|c|c|c|c|c|c|c|c|c|c|c|c|}
\hline & \multicolumn{4}{|c|}{ All Nonelderly Singles and Families } & \multicolumn{4}{|c|}{ Nonelderly, Head $<=12$} & \multicolumn{4}{|c|}{$\underline{\text { Female Headed Households }}$} & \multicolumn{4}{|c|}{$\underline{\text { Nonwhite Female Headed Households }}$} \\
\hline & $\mathrm{N}$ & Mean & Min & $\operatorname{Max}$ & $\mathrm{N}$ & Mean & Min & $\operatorname{Max}$ & $\mathrm{N}$ & Mean & Min & $\operatorname{Max}$ & $\mathrm{N}$ & Mean & Min & Max \\
\hline FSP participation & 43693 & 0.068 & 0 & 1 & 34084 & 0.087 & 0 & 1 & 6608 & 0.289 & 0 & 1 & 4951 & 0.439 & 0 & 1 \\
\hline Head any work last year & 48168 & 0.926 & 0 & 1 & 37474 & 0.904 & 0 & 1 & 7280 & 0.707 & 0 & 1 & 5464 & 0.615 & 0 & 1 \\
\hline Head Annual hours & 48168 & 1947 & 0 & 5824 & 37474 & 1879 & 0 & 5824 & 7280 & 1068 & 0 & 4628 & 5464 & 864 & 0 & 4628 \\
\hline Head Annual earnings & 48168 & 41742 & 0 & 503346 & 37474 & 34600 & 0 & 439860 & 7280 & 14194 & 0 & 117854 & 5464 & 10022 & 0 & 75516 \\
\hline Spouse any work last year & 31443 & 0.556 & 0 & 1 & 23797 & 0.544 & 0 & 1 & & & & & & & & \\
\hline Spouse annual hours & 31443 & 9840 & 0 & 116806 & 23797 & 8732 & 0 & 103129 & & & & & & & & \\
\hline Spouse annual earnings & 31443 & 710 & 0 & 7980 & 23797 & 704 & 0 & 7980 & & & & & & & & \\
\hline Log(Family Income) & 48168 & 10.763 & 6.617 & 13.129 & 37474 & 10.645 & 6.645 & 12.994 & 7280 & 10.193 & 6.714 & 12.640 & 5464 & 9.939 & 6.714 & 11.781 \\
\hline County FSP prorgam implemented & 48168 & 0.760 & 0 & 1 & 37474 & 0.761 & 0 & 1 & 7280 & 0.804 & 0 & 1 & 5464 & 0.821 & 0 & 1 \\
\hline Urban county & 48168 & 0.622 & 0 & 1 & 37474 & 0.595 & 0 & 1 & 7280 & 0.669 & 0 & 1 & 5464 & 0.724 & 0 & 1 \\
\hline Education $<12$ years & 48168 & 0.335 & 0 & 1 & 37474 & 0.487 & 0 & 1 & 7280 & 0.481 & 0 & 1 & 5464 & 0.608 & 0 & 1 \\
\hline Education $=12$ years & 48168 & 0.353 & 0 & 1 & 37474 & 0.513 & 0 & 1 & 7280 & 0.376 & 0 & 1 & 5464 & 0.304 & 0 & 1 \\
\hline Education $>12$ years & 48168 & 0.312 & 0 & 1 & 37474 & 0 & 0 & 0 & 7280 & 0.142 & 0 & 1 & 5464 & 0.088 & 0 & 1 \\
\hline White & 48168 & 0.857 & 0 & 1 & 37474 & 0.823 & 0 & 1 & 7280 & 0.634 & 0 & 1 & 5464 & 0.000 & 0 & 0 \\
\hline State unemployment rate & 48168 & 5.82 & 2 & 12.5 & 37474 & 5.74 & 2 & 12.5 & 7280 & 6.00 & 2 & 12.5 & 5464 & 5.99 & 2 & 12.5 \\
\hline County \% black, 1960 & 48168 & 9.68 & 0 & 81.3 & 37474 & 9.90 & 0 & 81.3 & 7280 & 12.39 & 0 & 62.1 & 5464 & 19.72 & 0.1 & 62.1 \\
\hline County \% urban, 1960 & 48168 & 70.15 & 0 & 100 & 37474 & 67.06 & 0 & 100 & 7280 & 74.98 & 0 & 100 & 5464 & 81.99 & 0 & 100 \\
\hline County \% farmland, 1960 & 48168 & 44.75 & 0 & 239.8 & 37474 & 45.54 & 0 & 239.8 & 7280 & 41.36 & 0 & 126.6 & 5464 & 36.37 & 0 & 116.2 \\
\hline County \% ?\$3,000, 1960 & 48168 & 20.94 & 5.5 & 74.4 & 37474 & 22.09 & 5.5 & 74.4 & 7280 & 20.52 & 5.5 & 68 & 5464 & 21.52 & 5.5 & 68 \\
\hline County $\%<5$ years, 1960 & 48168 & 11.25 & 5.6 & 18.2 & 37474 & 11.19 & 5.6 & 18.2 & 7280 & 11.21 & 6.7 & 18.2 & 5464 & 11.26 & 7.4 & 15.1 \\
\hline County $\%>65$ years, 1960 & 48168 & 9.28 & 1 & 24.9 & 37474 & 9.39 & 1 & 24.9 & 7280 & 9.25 & 2.8 & 24.9 & 5464 & 8.96 & 2.8 & 24.9 \\
\hline $\log (1960$ county population $)$ & 48168 & 12.29 & 7.72 & 15.61 & 37474 & 12.15 & 7.72 & 15.61 & 7280 & 12.64 & 7.72 & 15.61 & 5464 & 13.19 & 8.74 & 15.61 \\
\hline County per cap ret. and dis. & 48168 & 983.03 & 0 & 23532 & 37474 & 992.42 & 0 & 23532 & 7280 & 1025.32 & 0 & 23532 & 5464 & 985.65 & 0 & 4539.11 \\
\hline County per cap medical payments & 48168 & 219.00 & 0 & 6646.72 & 37474 & 216.82 & 0 & 6646.72 & 7280 & 236.25 & 0 & 6646.72 & 5464 & 246.56 & 0 & 1282.09 \\
\hline County per cap cash PA payments & 48168 & 224.99 & 0 & 14071 & 37474 & 224.54 & 0 & 14071 & 7280 & 284.00 & 0 & 14071 & 5464 & 332.98 & 0 & 2714.17 \\
\hline
\end{tabular}

Note: PSID interview years 1968-78. Observations from Alaska are dropped because of missing data on food stamp program start dates. All outcome variables correspond to annual measures taken as of the interview (in spring of the interview year). 
Appendix Table 4: 1969 Food Stamp Price Schedule

(Price charged for total monthly coupon allocation, prior to the 1978 elimination of the purchase requirement)

\begin{tabular}{|c|c|c|c|}
\hline & $\begin{array}{c}\text { Family } \\
\text { size }=2 \\
(1)\end{array}$ & $\begin{array}{c}\text { Family } \\
\text { size =3 } \\
(2)\end{array}$ & $\begin{array}{c}\text { Family } \\
\text { size }=4 \\
(3) \\
\end{array}$ \\
\hline $\begin{array}{l}\text { Total monthly } \\
\text { coupon } \\
\text { allocation }\end{array}$ & 56 & 84 & 106 \\
\hline $\begin{array}{l}\text { Monthly income } \\
\text { range }\end{array}$ & \multicolumn{3}{|c|}{ Monthly purchase price } \\
\hline $0-19$ & 1 & 1.5 & 2 \\
\hline $20-29$ & 1 & 1.5 & 2 \\
\hline $30-39$ & 4 & 4 & 4 \\
\hline $40-49$ & 7 & 7 & 7 \\
\hline $50-59$ & 10 & 10 & 10 \\
\hline $60-69$ & 12 & 13 & 13 \\
\hline $70-79$ & 15 & 16 & 16 \\
\hline $80-89$ & 18 & 19 & 19 \\
\hline $90-99$ & 21 & 21 & 22 \\
\hline $100-109$ & 23 & 24 & 25 \\
\hline $110-119$ & 26 & 27 & 28 \\
\hline $120-129$ & 29 & 30 & 31 \\
\hline $130-139$ & 31 & 33 & 34 \\
\hline $140-149$ & 34 & 36 & 37 \\
\hline $150-169$ & 36 & 40 & 42 \\
\hline $170-189$ & & 46 & 48 \\
\hline $190-209$ & & 52 & 54 \\
\hline $210-229$ & & 58 & 60 \\
\hline $230-249$ & & 64 & 66 \\
\hline $250-269$ & & 66 & 72 \\
\hline $270-289$ & & & 72 \\
\hline $290-309$ & & & 76 \\
\hline $310-329$ & & & 80 \\
\hline $330-359$ & & & 80 \\
\hline 360 and higher & & & 82 \\
\hline
\end{tabular}

